\title{
Democratic Republic of Timor-Leste: 2011 Article IV Consultation-Staff Report; Informational Annex; Debt Sustainability Analysis; and Public Information Notice
}

Under Article IV of the IMF's Articles of Agreement, the IMF holds bilateral discussions with members, usually every year. In the context of the 2011 Article IV consultation with the Democratic Republic of Timor-Leste, the following documents have been released and are included in this package:

- $\quad$ The staff report for the 2011 Article IV consultation, prepared by a staff team of the IMF, following discussions that ended on November 24, 2011, with the officials of Timor-Leste on economic developments and policies. Based on information available at the time of these discussions, the staff report was completed on January 13, 2012. The views expressed in the staff report are those of the staff team and do not necessarily reflect the views of the Executive Board of the IMF.

- $\quad$ A Debt Sustainability Analysis Report.

- $\quad$ A Public Information Notice (PIN) summarizing the views of the staff report that concluded the Article IV consultation.

The policy of publication of staff reports and other documents allows for the deletion of market-sensitive information.

\author{
Copies of this report are available to the public from \\ International Monetary Fund • Publication Services \\ $70019^{\text {th }}$ Street, N.W. $\bullet$ Washington, D.C. 20431 \\ Telephone: (202) 623-7430 • Telefax: (202) 623-7201 \\ E-mail: publications@imf.org Internet: http://www.imf.org
}

\section{International Monetary Fund Washington, D.C.}




\section{INTERNATIONAL MONETARY FUND}

\section{DEMOCRATIC REPUBLIC OF TIMOR-LESTE}

\section{STAFF REPORT FOR THE 2011 ARTICLE IV CONSULTATION}

January 13, 2012

\section{KEY ISSUES}

Context. After emerging from a long struggle for independence and internal conflicts between 1999 and 2006, Timor-Leste has made substantial progress toward restoring stability and rebuilding the country. Rising government spending has supported strong economic growth, but inflation has increased to double digits. The government launched its Strategic Development Plan to step up development.

Focus. Discussions centered on an appropriate fiscal stance to manage near-term inflation risks and sustain high growth, and on financial sector development.

Fiscal stance. The planned investment in infrastructure is welcome, but given doubledigit inflation, staff advised slowing the planned increase in capital spending over the next few years to better align with the absorptive capacity of the economy and administrative constraints. In the absence of monetary policy (Timor-Leste uses the U.S. dollar), sound fiscal policy is key to containing high inflation and sustaining strong growth. Staff supported the government's plan to reduce the non-oil fiscal balance to a sustainable level over the next 10 years, to provide an anchor for fiscal policy.

Public financial management (PFM). The government has improved the PFM system. A well managed Petroleum Fund is in place, and new institutions have been established to manage large public investment programs. The authorities need to further strengthen institutional capacities and develop human resources.

Financial sector. Foreign bank branches dominate the sector, but financial services are underdeveloped and nonperforming loans are high. Developing the financial sector and strengthening the credit culture are crucial for sustained growth in the private sector. 
Approved By

Ray Brooks and

Dhaneshwar Ghura
Discussions took place in Dili during November 11-24, 2011. The staff team comprised Messrs. Jang (head), Kataoka, Ochirkhuu, Tan (all APD). A World Bank team joined the mission and Mr. Cardoso (OED) participated in the discussions. Mr. Zavadjil, Resident Representative in Indonesia, joined the mission toward the end.

\section{CONTENTS}

FROM CONFLICT TO PROSPERITY

RECENT DEVELOPMENTS AND OUTLOOK

SECURING SUSTAINABLE HIGH GROWTH _ 7

$\begin{array}{ll}\text { A. Fiscal Policy_ } & 7 \\ \text { B. Financial Sector Policy } & 14 \\ \text { C. Exchange Rate and External Stability } & 15 \\ \text { D. Other Issues } & 16\end{array}$

STAFF APPRAISAL

\section{BOXES}

1. Infrastructure Development Needs __ 4

2. Inflation and the Poor __ 9

3. Poverty and Food Security in Timor-Leste___ 13

\section{FIGURES}

1. Macroeconomic Developments 19

2. Policy Developments _ 20

3. Cross-Country Perspective __ 21

\section{TABLES}

1. Selected Economic and Financial Indicators, 2007-12 __ 22

2. Summary Operations of the Central Government, 2008-16___ 23

3. Monetary Developments, 2006-11__ 24

4. Balance of Payments, 2008-16__ 25

5. Medium-Term Scenario, 2008-16__ 26

6. Millennium Development Goals Progress, 1990-2009__ 27

\section{APPENDIX}

I. Timor-Leste's Petroleum Fund and Estimated Sustainable Income __ 28 


\section{FROM CONFLICT TO PROSPERITY}

1. Context. After emerging from a 24year struggle for independence and internal conflicts between 1999 and 2006, Timor-Leste has made substantial progress toward restoring stability and rebuilding the country. The first decade after Timor-Leste's independence in 2002 saw a significant rise in national income and improvements in human development indicators, thanks to petroleum and sound policies. Petroleum income accounted for about 270 percent of non-oil GDP, as of 2010. The country is still in the process of building its administration and governmental institutions.

\section{Strategic Development Plan (SDP).}

The government launched the SDP in 2011, with donor support, to transform Timor-Leste from a low-income to an upper-middleincome country by 2030 . The SDP aims for rapid, inclusive growth by improving infrastructure, worker skills, education, training and health systems, and by combating malnutrition. The majority of the country's infrastructure (including the electric grid, irrigation and water supply, housing and schools) was destroyed in the 1999 conflict (Box 1).

3. Politics. Presidential and parliamentary elections are set for March and June 2012. Donors expect the elections to take place smoothly and the UN mission (UNMIT) and international security force should leave Timor-Leste by end-2012. The government and UNMIT have begun joint planning for UNMIT's withdrawal. The impact of UNMIT's withdrawal on the economy is expected to be limited (text table).

\begin{tabular}{|lrr|}
\hline \multicolumn{3}{|c|}{ UNMIT's Local Spending } \\
\hline & 2010 & Percent \\
\cline { 2 - 3 } & Million \$ & of GDP 1/ \\
Local procurement & 5.3 & 0.1 \\
Payments to national staff & 6.4 & 0.1 \\
Local payments to international staff & 34.9 & 0.8 \\
\hline Sources: UNMIT and IMF staff calculations. & \\
1/ In percent of projected 2011 GDP. & \\
\hline
\end{tabular}

4. Past advice. The authorities have made progress in implementing past advice. New institutions were established to strengthen public investment management, fiscal transparency has been improved further, and financial supervision and regulations have been strengthened. The 2011 budget increased spending sharply to improve poor infrastructure, while most Directors had suggested a more gradual increase in such spending in the last Article IV consultation. 


\section{Box 1. Infrastructure Development Needs}

Infrastructure bottlenecks are a fundamental constraint to economic development in Timor-Leste. According to the Global Competitiveness Report 2011-12, inadequate infrastructure is the most problematic factor for doing business in Timor-Leste, and Timor-Leste ranks at the bottom in the Asia Pacific region and among fragile states, marked by an inadequate electricity supply and poor roads.

\begin{tabular}{lcccccc}
\multicolumn{7}{c}{ Comparision of Infrastructure Quality, $\mathbf{2 0 1 0}$} \\
\hline Region/Country & $\begin{array}{l}\text { Country } \\
\text { Ranking }\end{array}$ & $\begin{array}{c}\text { Overall } \\
\text { Infrastructure }\end{array}$ & Roads & Port & Air Transport & Electricity \\
\hline World (average) & 66 & 4.3 & 4.0 & 4.3 & 4.7 & 4.5 \\
Developing Asia (average) & 82 & 3.9 & 3.8 & 3.9 & 4.4 & 3.6 \\
Malaysia & 23 & 5.7 & 5.7 & 5.7 & 6.0 & 5.9 \\
Brunei & 44 & 5.0 & 5.2 & 4.4 & 4.9 & 5.4 \\
Cambodia & 76 & 4.1 & 4.0 & 4.0 & 4.3 & 3.5 \\
Indonesia & 82 & 3.9 & 3.5 & 3.6 & 4.4 & 3.7 \\
Ethiopia & 98 & 3.6 & 2.9 & 3.9 & 5.3 & 2.8 \\
Coted'Ivoire & 102 & 3.6 & 2.9 & 4.9 & 4.3 & 3.3 \\
Vietnam & 123 & 3.1 & 2.6 & 3.4 & 4.1 & 3.3 \\
Nigeria & 125 & 3.0 & 2.7 & 3.3 & 3.9 & 1.5 \\
Bangladesh & 129 & 2.8 & 2.9 & 3.4 & 3.5 & 1.6 \\
Chad & 130 & 2.8 & 3.0 & 2.7 & 3.2 & 1.5 \\
Nepal & 132 & 2.7 & 2.5 & 2.6 & 3.4 & 1.3 \\
Timor-Leste & 138 & 2.5 & 2.1 & 2.6 & 3.1 & 1.8 \\
Angola & 141 & 2.1 & 2.5 & 2.3 & 3.1 & 1.4 \\
\hline
\end{tabular}

Source: World Economic Forum, The Global Competitiveness Report 2011-12.

The infrastructure of Timor-Leste was largely destroyed in the 1999 civil conflict. One third of the population has no access to improved drinking water, 60 percent lack decent sanitation facilities, and two thirds are living without electricity. Around 90 percent of roads are in poor condition and seaport, airport, and telecommunications need urgent improvements.

Fragile States: Infrastructure and Government Capital Spending

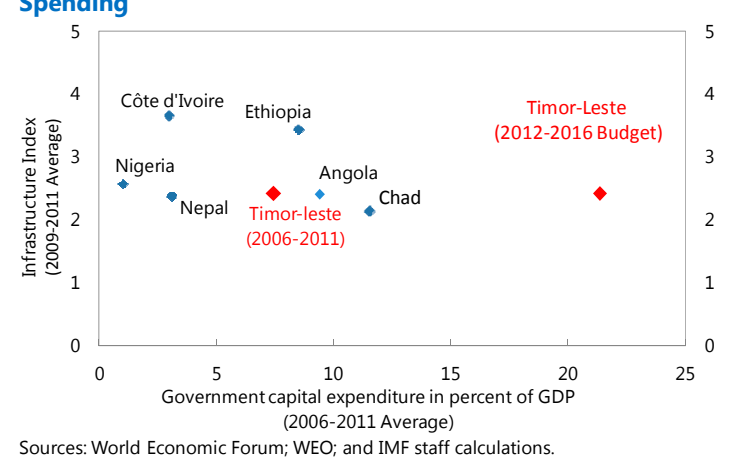

Sources: World Economic Forum; WEO; and IMF staff calculations.
The SDP puts infrastructure development as a central pillar to promote the country's development. To improve poor infrastructure, capital spending has increased rapidly and is expected to remain very high compared with that of other countries, including fragile states (text figure). The government is focusing on electricity, roads, and the rural housing program. It is also investing in infrastructure on the South Coast to attract investment in the downstream petroleum sector.

\begin{tabular}{|c|c|c|c|c|}
\hline \multicolumn{5}{|c|}{$\begin{array}{l}\text { Timor-Leste: Central Government Budget } \\
\text { (In millions of U.S. dollars) }\end{array}$} \\
\hline & $\begin{array}{l}2010 \\
\text { Actual }\end{array}$ & 2011 & $\frac{2012}{\text { Budget }}$ & $2013-16$ \\
\hline Total government spending & 794 & 1,306 & 1,763 & 6,728 \\
\hline Recurrent & 527 & 588 & 679 & 3,031 \\
\hline Capital & 268 & 718 & 1,084 & 3,697 \\
\hline Of which: & & & & \\
\hline Electricity grid and power plants & & 447 & 282 & \\
\hline Tasi Mane program & & 19 & 163 & 220 \\
\hline Suai-Beacu highway & & & & 722 \\
\hline Roads and drainage projects financed with loans & & & 43 & 577 \\
\hline MDG-Suco program & & 45 & 55 & 135 \\
\hline
\end{tabular}

To better manage large public investment programs, the government established several new institutions. In 2011 the Infrastructure Fund was set up to facilitate the development of large, multi-year projects. The Secretariat of Major Projects at the MOF was given responsibility for reviewing projects proposed by line ministries, and the final approval is decided either by the Board of the Infrastructure Fund (for projects less than $\$ 5$ million), or by the Council of Ministers (for projects above $\$ 5$ million). The National Development Agency was established to supervise project implementation, and the Procurement Commission to assist in the procurement for large scale projects undertaken by the Infrastructure Fund.

Large infrastructure spending is mainly to be financed by withdrawals from the Petroleum Fund. The government is also considering other financing options such as borrowing and publicprivate partnerships (PPPs). 


\section{RECENT DEVELOPMENTS AND OUTLOOK}

5. Growth and inflation. Rising

government spending and a rebound in agriculture supported strong non-oil GDP growth since 2007, averaging 12 percent

(Table 1 and Figure 1). Despite unseasonal rain that damaged agricultural produce, staff estimates growth in 2011 to remain strong at about 10 percent on the back of high government spending. Inflation in Dili rose to $14 \frac{1}{2}$ percent $(y / y)$ in October and is becoming broad-based.

6. Fiscal performance. To improve poor infrastructure, capital expenditure has increased sharply in 2011 with total government spending estimated to rise to $\$ 1.2$ billion from $\$ 0.8$ billion in 2010 (Table 2 and Figure 2). Owing to large petroleum revenue, however, the overall balance is expected to continue to record a large surplus of 50 percent of GDP in 2011 and the Petroleum Fund (PF) has risen to about $\$ 9$ billion (text figures).

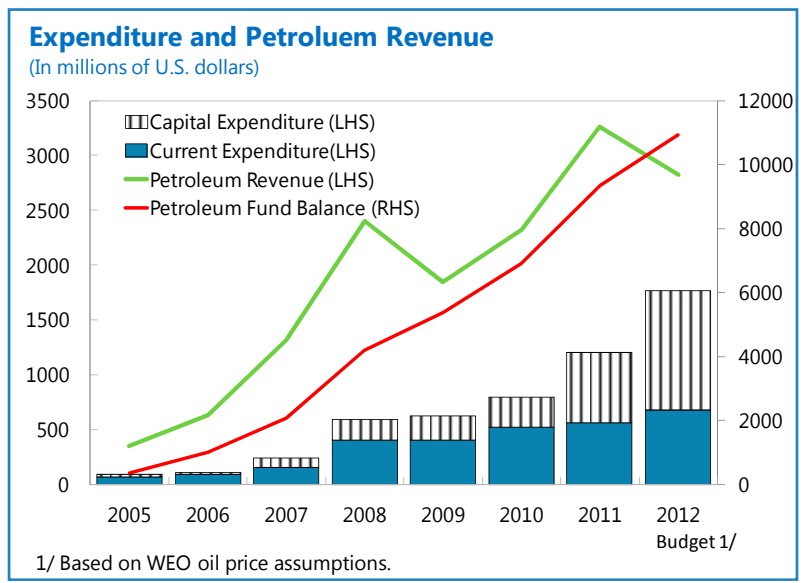

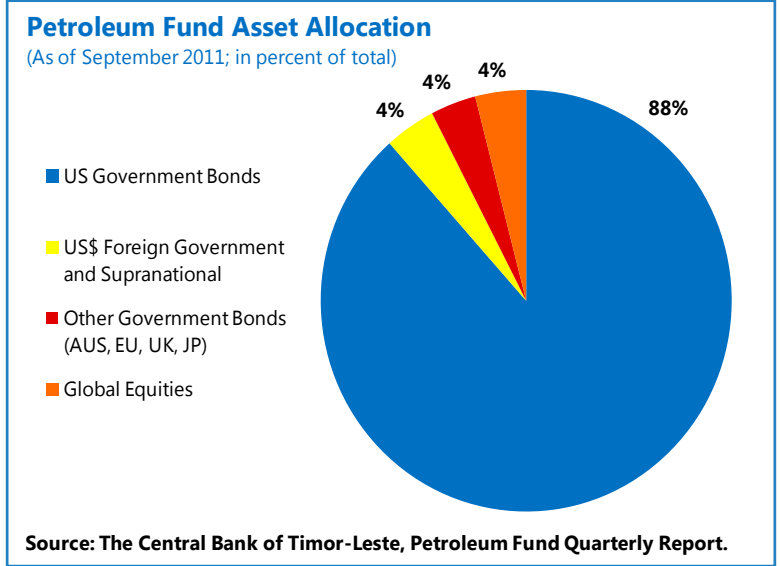

7. Financial sector. Credit to the private sector has started rising after being stagnant for a few years (Table 3). However, it remains low at only 13 percent of non-oil GDP, reflecting the lack of collateral and weak contract enforcement. These weaknesses together with high nonperforming loans (NPLs) have contributed to high lending rates in Timor-Leste (text figure). NPLs are fully covered by provisions (text table), and banks tightened lending standards and improved credit assessments.

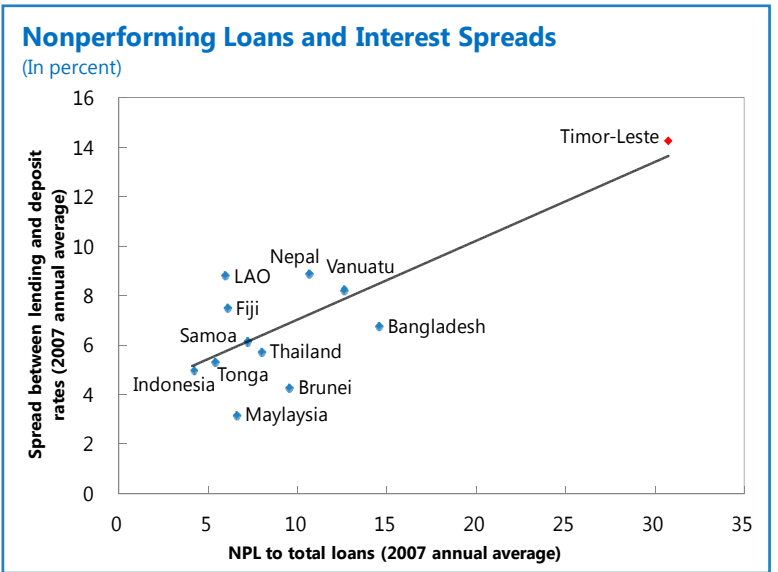




\begin{tabular}{|lrrr|}
\hline \multicolumn{4}{|c|}{ Timor-Leste: Financial Soundness Indicators } \\
(In percent) \\
\hline \multicolumn{4}{|c|}{} \\
& 2009 & 2010 & 2011 \\
& $\mathrm{Q} 4$ & $\mathrm{Q} 4$ & $\mathrm{Q} 3$ \\
\hline Return on assets 1/ & 1.73 & 0.31 & 0.58 \\
NPLs/total loans & 32.1 & 41.7 & 39.1 \\
Total provisions/NPLs & 162.6 & 131.7 & 125.4 \\
Loans/deposits & 38.4 & 36.5 & 43.0 \\
\hline Source: The Central Bank of Timor-Leste. & & \\
1/ Data for 2011 is as of Q2. & \\
\hline
\end{tabular}

8. Three foreign bank branches (Australian, Indonesian, and Portuguese) dominate the financial sector. Their parent banks are profitable with capital above regulatory minimums (text table). A small state-owned microfinance institution recently became the first locally incorporated bank. The Banking and Payments Authority was transformed to a central bank, with no change in its function. Timor-Leste uses the U.S. dollar, so has no independent monetary policy.

\begin{tabular}{|c|c|c|c|}
\hline \multicolumn{4}{|c|}{$\begin{array}{l}\text { Parent banks' Financial Soundness Indicators } \\
\text { (In percent; as of end-2010) }\end{array}$} \\
\hline & ANZ 1/ & $\begin{array}{r}\text { Bank } \\
\text { Mandiri }\end{array}$ & $\begin{array}{r}\text { Caixa Geral } \\
\text { de Depositos }\end{array}$ \\
\hline \multicolumn{4}{|c|}{ Capital adequacy ratio } \\
\hline Tier 1 & 10.9 & 10.5 & 8.9 \\
\hline Total & 12.1 & 13.4 & 12.3 \\
\hline Return on equity & 15.3 & 24.4 & 4.1 \\
\hline Return on assets & 1.0 & 3.4 & 0.3 \\
\hline $\begin{array}{l}\text { Sources: Banks' a } \\
\text { 1/ As of Septembe }\end{array}$ & & & \\
\hline
\end{tabular}

\section{External position. Staff estimates a} continued large current account surplus of over 50 percent of GDP in 2011 due to high oil revenue (Table 4). Timor-Leste exports little, except petroleum and coffee, and depends heavily on imports. Foreign assets (mostly in the PF) have risen to an all-time high at 170 months of imports.

10. Outlook. The outlook for growth and poverty reduction is promising, as Timor-Leste stands to benefit enormously from its petroleum wealth in coming years. Using this wealth, the government has resolved to step up development. With rising government spending, staff projects growth to remain strong at about 10 percent in 2012 and over the medium term (Table 5).

11. Risks. Key risks to the outlook are high inflation, a fall in oil prices, and slow progress in building public financial management capacity.

- $\quad$ On the external front, global growth could stall, hitting oil revenue and income from the PF. A permanent fall in oil prices to $\$ 50$ a barrel would reduce the estimated sustainable income (ESI) from petroleum by almost 40 percent to just over $\$ 0.4$ billion.

Deleveraging by the Portuguese bank is a limited risk. Even if it cuts its lending by half, private sector credit would decline only by about 1 percent of non-oil GDP. 


$$
\begin{aligned}
& \text { Domestically, the planned large } \\
& \text { increases in fiscal spending could } \\
& \text { maintain inflation above } 10 \text { percent } \\
& \text { given the small non-oil economy. In } \\
& \text { turn, high inflation could push back } \\
& \text { progress on poverty reduction and } \\
& \text { lead to a real currency appreciation } \\
& \text { that would hurt private-sector-led } \\
& \text { growth. }
\end{aligned}
$$

- Limited progress on plans to improve government institutions could undermine public financial management and reduce the effectiveness of large public investment.

\section{Authorities' Views}

\section{The authorities broadly agreed with} staff's assessment of the economy and outlook. They noted that in a relatively short period of time, Timor-Leste as a young nation has made strong progress in moving forward as a secure and stable nation and in laying down the foundations for government institutions and good governance. As envisaged in the SDP, the government is now focusing on improving inadequate infrastructure, particularly electricity and roads, which will lessen the key constraints to economic development and enhance growth potential. To better manage large public investment programs, the government established new agencies that are responsible for project appraisal, procurement, and monitoring.

\section{SECURING SUSTAINABLE HIGH GROWTH}

\section{A. Fiscal Policy}

\section{Developments. The government} launched the SDP to transform Timor-Leste into an upper-middle-income country by 2030. To achieve this goal, it plans to scale up public investment to improve poor infrastructure. The proposed 2012 Budget envisages another scaling up of capital spending so total government spending would rise to $\$ 1.8$ billion, an increase of about 45 percent over
2011 spending and more than twice the level of the ESI of $\$ 0.7$ billion (Appendix I). ${ }^{1}$ Given high oil revenue, the PF balance is projected to continue to rise, but the non-oil fiscal deficit to increase to over 100 percent of non-oil GDP.

\footnotetext{
${ }^{1}$ The authorities' calculation of the ESI is conservative. The ESI would increase by about $\$ 160$ million if the WEO oil price assumptions were used and by another $\$ 250$ million if the Greater Sunrise oil field is included. Moreover, the assumed rate of return on PF investments is a 10-year average of US Treasury bond yields.
} 

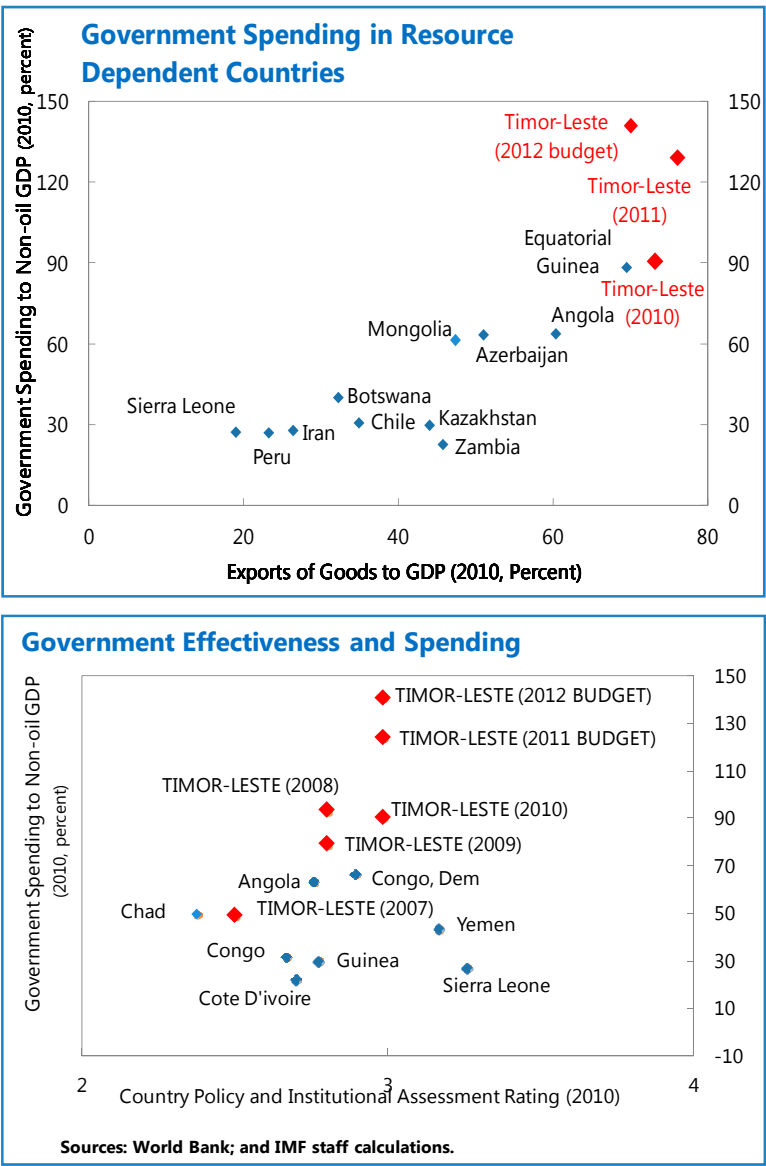

14. Fiscal stance. While noting the need to frontload investment in infrastructure, staff encouraged the government to consider the following in determining the pace of spending over the next few years:

- Inflation has increased and price pressures are likely to continue given strong demand and the planned large increases in fiscal spending. Other countries' experiences suggest that high inflation would impose significant costs on the poor (Box 2).
- There is a risk that inflation expectations could become untethered, requiring difficult disinflation policies down the road.

In the absence of monetary policy, sound fiscal policy to increase government spending gradually is key to containing high inflation and sustaining strong economic growth.

With the Infrastructure Fund in place to manage large, multi-year projects, it would be possible to phase the spending in a manner that is better aligned with capacity constraints and the absorptive capacity of the economy. ${ }^{2}$

\section{To rebuild infrastructure and deliver} sustainable high growth with moderate inflation, staff advised slowing the planned rise of capital spending over the next few

years. This would imply lower spending in coming years, while keeping total capital spending over the next five years in line with the authorities' plan (text figure and table).

\footnotetext{
${ }^{2}$ According to the World Bank's Country Policy and Institutional Assessment (CPIA) index, which measures the quality of policies and institutions, Timor-Leste is still classified as a "weak" performer despite the recent improvements.
} 


\section{Box 2. Inflation and the Poor}

Inflation in Timor-Leste has remained in double digits and above that of other Asian low income countries from early 2011. Inflation picked up following the rise in global commodity prices in 2010. Imported and local food inflation has been the main driver of inflation, but non-food inflation has also risen to double digits, contributing 4 percentage points to inflation. Timor-Leste is a net importer of foods, and food comprises about 60 percent of its consumer price index basket, placing it above other Asian low income countries. A weak US dollar and strong demand from rising government spending have also contributed to the high inflation.

\section{A few factors distinguish the current inflation episode from the one in 2007-08. Staff estimates indicate that the contribution of local inflation to headline inflation is much bigger and persistent this time and that local inflation is about 5 percentage points higher than imported inflation. Local products and services are estimated to comprise about}

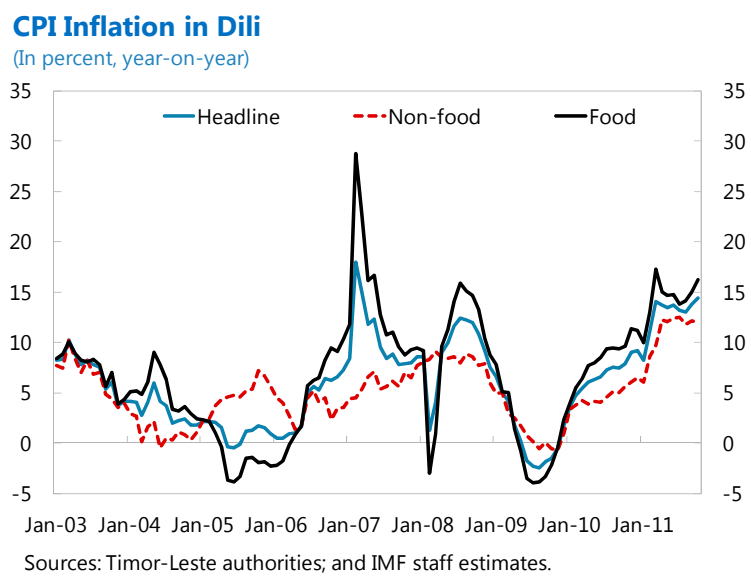

Contributions to CPI Inflation in Dili (In percent, year-on-year)

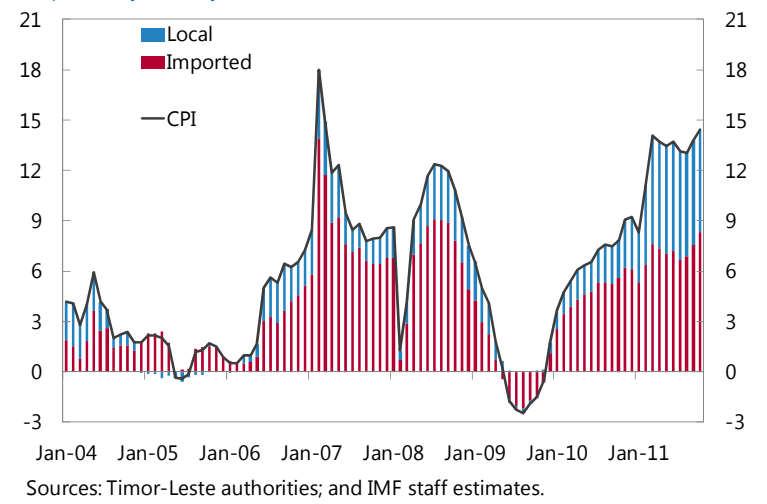

39 percent of household consumption (47 percent of food consumption and 27 percent of non-food consumption). Government spending has more than tripled since 2007 and continues to rise rapidly, which has increased inflationary pressure given the small non-oil economy. In 2008, the government introduced a rice subsidy program to dampen the impact of rising global rice prices, but the subsidy program will end soon. Rice is the main staple and comprises about 15 percent of the CPI basket. Moreover, wage pressures are reportedly rising recently but no reliable data are available.

\section{Previous studies indicate that the poor suffer more} from inflation than the rich do. Easterly and Fischer (2000), ${ }^{1}$ for example, found that the poor are more likely than the rich to mention inflation as a top concern and that high inflation tends to lower the income share of the bottom quintile and increase poverty. Agenor (1998) also found poverty rates to be positively related to inflation in cross-country data. ${ }^{2}$ A recent ADB study estimates that a 10 percent rise in food prices in Timor-Leste could increase poverty incidence by $2 \frac{1}{4}$ percentage points. $^{3}$

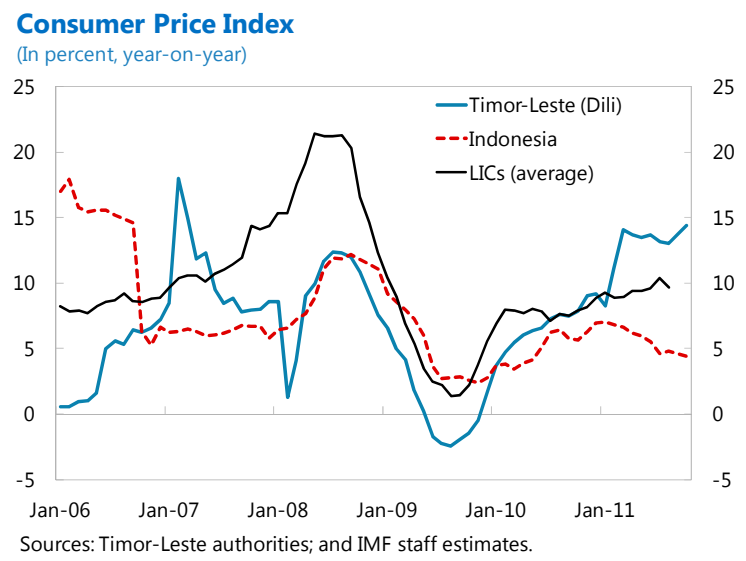

Contributions to CPI Inflation in Dili

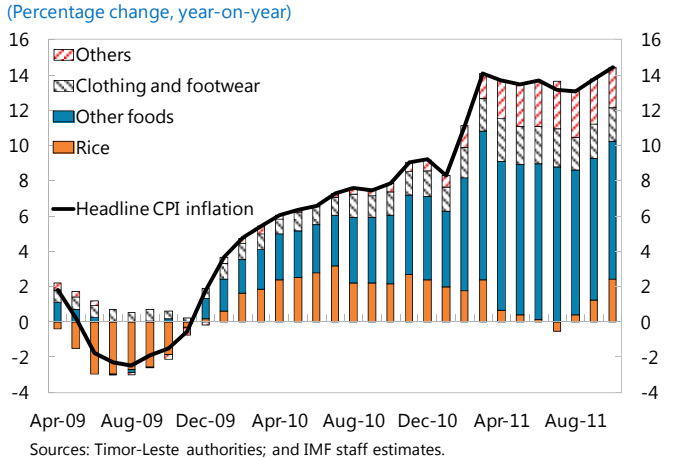

${ }^{1}$ Easterly, W., and S. Fischer, "Inflation and the Poor." World Bank Policy Research Working Paper 2334 (May 2000).

${ }^{2}$ Agenor, P., "Stabilization Policies, Poverty, and the Labor Market," IMF and World Bank (1998).

${ }^{3}$ Asian Development Bank, Global Food Inflation and Developing Asia (March 2011). 
Timor-Leste: Medium-Term Fiscal Outlook

\begin{tabular}{|c|c|c|c|c|c|c|c|c|c|}
\hline & 2008 & 2009 & 2010 & 2011 & 2012 & 2013 & 2014 & 2015 & 2016 \\
\hline & \multicolumn{9}{|c|}{2012 Proposed Budget } \\
\hline Real non-oil GDP growth (percent) & 14.6 & 12.8 & 9.5 & 10.6 & 10.9 & 10.4 & 9.9 & 10.8 & 11.5 \\
\hline Total government expenditure (in millions of U.S. dollars) $1 /$ & 594 & 627 & 794 & 1206 & 1763 & 1804 & 1855 & 1506 & 1564 \\
\hline (In percent of non-oil GDP) & 93.6 & 79.4 & 90.7 & 114.5 & 140.8 & 121.3 & 105.0 & 71.7 & 62.7 \\
\hline Non-oil overall balance (percent of non-oil GDP) & -85.3 & -71.1 & -81.1 & -104.0 & -130.0 & -110.6 & -94.5 & -61.4 & -52.4 \\
\hline \multirow[t]{2}{*}{ Petroleum Fund balance (in millions of U.S. dollars) } & 4197 & 5377 & 6904 & 9338 & 10565 & 11674 & 12509 & 13854 & 15242 \\
\hline & \multicolumn{9}{|c|}{ Alternative Scenario } \\
\hline Real non-oil GDP growth (percent) & 14.6 & 12.8 & 9.5 & 10.6 & 10.0 & 10.0 & 10.0 & 10.0 & 10.0 \\
\hline Total government expenditure (in millions of U.S. dollars) & 594 & 627 & 794 & 1206 & 1416 & 1539 & 1647 & 1754 & 1859 \\
\hline (In percent of non-oil GDP) & 93.6 & 79.4 & 90.7 & 114.5 & 113.1 & 103.5 & 93.2 & 83.5 & 74.5 \\
\hline Non-oil overall balance (percent of non-oil GDP) & -85.3 & -71.1 & -81.1 & -104.0 & -102.2 & -92.8 & -82.7 & -73.2 & -64.3 \\
\hline Petroleum Fund balance (in millions of U.S. dollars) & 4197 & 5377 & 6904 & 9338 & 10923 & 12297 & 13340 & 14437 & 15530 \\
\hline
\end{tabular}

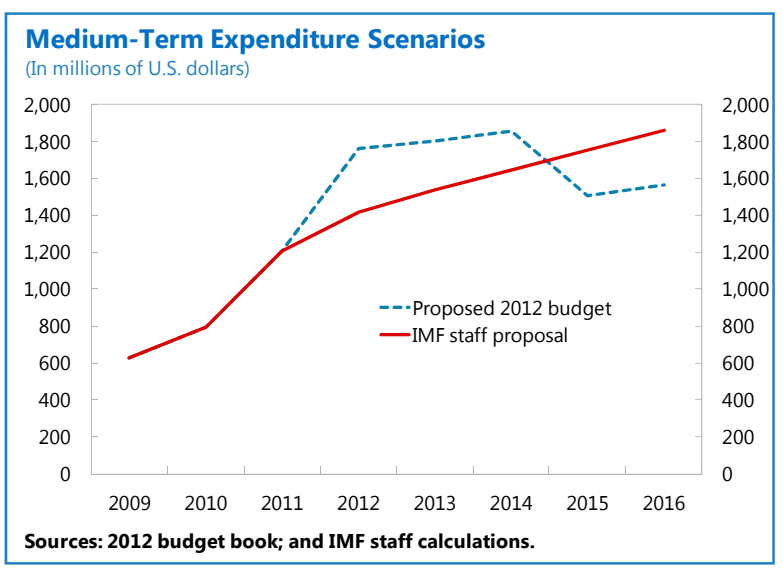

16. Longer-term fiscal policy. The government intends to reduce the non-oil fiscal balance to the level implied by the ESI over the next 10 years. Staff supported this goal as an anchor for fiscal policy. The government has started studying the longterm impact of the current fiscal stance and new capital spending initiatives. The SDP envisages excess withdrawals for the next two decades, which would bring down the ESI and PF by about 40 percent by 2030 (text figure).

Staff expressed concern that the current medium-term budget framework (MTBF) does not reflect the full costs of planned major projects and recurrent costs. Moreover, available information indicates that the planned current spending for 2013-16, including wages and fuel costs, could be underbudgeted. The authorities indicated that once the key basic infrastructure development is completed over the next several years, capital spending is expected to decline sharply.

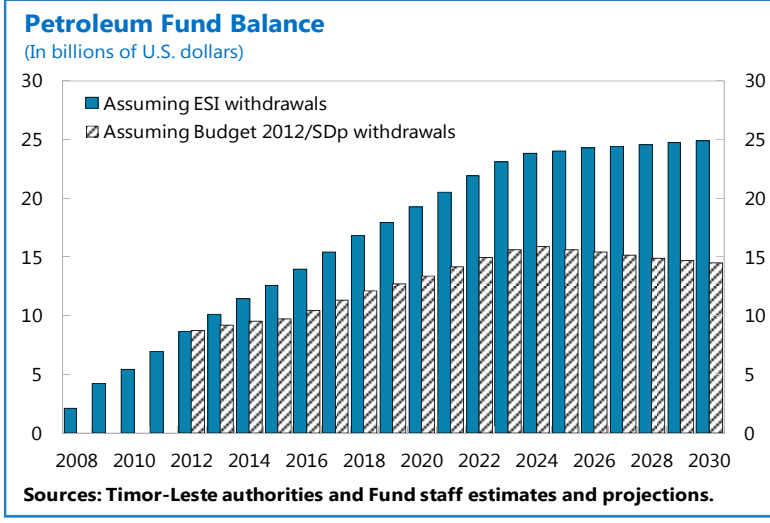

17. Staff noted that the 2012 budget and SDP scenario indicates that the government may need to take substantial measures (amounting to 10-15 percent of nonoil GDP) to reduce the non-oil fiscal balance to the ESI within $\mathbf{1 0}$ years. The 
measures could include containing spending growth and increasing domestic revenue, including by adjusting utility tariffs, changing tax rates and exemptions, strengthening tax administration, and introducing a Value Added tax (VAT) over the medium term. ${ }^{3}$ Non-oil tax revenue is less than 6 percent of non-oil GDP. The government may also consider repealing the costly and possibly ineffective tax holidays under a new private investment law, as recommended by the recent FAD TA mission.

\section{A downside scenario of lower global growth would imply further adjustments to}

the budget. The large size of the PF, however, would limit the impact of a fall in oil prices on the budget over the next few years. Over the long-term, a sharp and permanent fall in oil prices would require a considerable scaling back of spending plans to bring the non-oil fiscal balance into line with the lower ESI within 10 years. Another significant risk to the budget is possibly large recurrent costs related to the new major projects.

\section{Public financial management (PFM).}

Staff welcomed continued progress in addressing weaknesses in PFM. The fiscal report on the observance of standards and

\footnotetext{
${ }^{3}$ Timor-Leste's flat income tax rate at 10 percent is very low by regional standards and most personal income is untaxed. The FAD mission in November 2011 estimates that each percentage point of VAT could raise $1 / 2$ percent of non-oil GDP in revenue.
}

codes (ROSC) and Public Expenditure and Financial Accountability (PEFA) assessment in 2010 found that Timor-Leste made solid progress in improving the PFM system, including a well-managed PF and a transparent framework for the governance of the petroleum sector. To address the weaknesses identified in the two assessments, the government established new institutions to improve procurement and project appraisal and costing and further strengthened the treasury single account by closing line ministries' accounts at commercial banks. Line ministries should now utilize the new procurement system. Moreover, the government launched an online transparency portal, which allows public access to timely data on government spending. Staff supported the government's ongoing efforts to improve audits and the oversight of autonomous agencies. Given the lack of skilled personnel, the government set up the Human Capital Development Fund to speed up the training of Timorese by studying abroad. Staff welcomed these steps and encouraged further efforts to strengthen economic and policy analysis capacity.

20. Petroleum Fund. The PF remains the cornerstone for managing Timor-Leste's oilbased financial resources. The PF Law was amended in 2011 to allow higher investment in equities (up to 50 percent of the PF) and for 
the PF to be used to secure government borrowing (up to 10 percent of the PF). Staff noted that prudent management of the PF would be key to continued funding for the budget over the longer term. The authorities plan to gradually increase the share of equities with assistance from external consultants, particularly given volatile global financial markets. They requested TA from the Fund on PF asset management.

\section{External borrowing. An updated debt} sustainability analysis (DSA) continues to indicate a low risk of debt stress, despite higher borrowings envisaged compared with the previous DSA. Parliament approved, for the first time, concessional borrowing of \$43 million in 2012 from the World Bank, the $A D B$, and bilateral donors to finance infrastructure projects. More loans are envisaged over the medium term. These loans would help build the authorities' capacity to appraise and plan projects. Staff advised, however, that any borrowing should substitute, not complement, withdrawals from the PF. The government is building up a debt management system. It is also considering using PPPs for projects such as airports and seaports. PPPs can provide know-how from the private sector, helping overcome government capacity constraints. Staff noted the importance of having a sound PPP framework in place and that given other countries' experiences, PPPs could also be significant sources of fiscal risk, particularly depending on the assumption made on the usage of the envisaged project.

\section{Poverty and human development.}

Timor-Leste has introduced a wide range of social safety net programs, including benefits for veterans and the elderly, and public work programs have provided jobs, particularly in rural areas. Human development indicators have also improved, particularly in the health area (Table 6). Nonetheless, poverty incidence remained high at 41 percent in 2009 (Box 3). To reduce poverty further, the government is focusing on rural development, better targeted transfers, and improved databases for the safety net programs. Staff supported these efforts and noted that speeding up implementation of the national ID program would help avoid abuse and ensure support goes to those most in need.

\section{Authorities' Views}

\section{The authorities broadly shared}

staff's views. They stressed the need to rebuild basic infrastructure soon to address the key constraint to economic growth, but shared staff concerns about high inflation and its impact on the poor. They indicated that if inflation remains high in double digits, the government would consider adjusting the pace of budget execution, including delaying some 


\section{Box 3. Poverty and Food Security in Timor-Leste}

A recent World Bank study indicates a sharp decline in poverty to $\mathbf{4 1}$ percent in $\mathbf{2 0 0 9}$ from $\mathbf{5 0}$ percent in 2007. ${ }^{1}$ The decline is due to high economic growth and increased public spending, particularly on social protection programs and labor-intensive infrastructure works; moreover, poverty incidence spiked in 2007 because of the 2006 civil unrest and lower agricultural production. The 2011 living standards survey outcomes with the latest poverty estimates will be available in 2012 .

The poverty line in Timor-Leste was $\mathbf{\$ 0 . 8 8}$ per day in 2007, which increased from $\$ 0.52$ in 2001 . The $\$ 0.88$ per day represents, in December 2007 prices, the typical cost of attaining 2,100 calories per day (\$0.54) and meeting some basic non-food needs (\$0.34). The extreme poverty line was $\$ 0.71$ per day, below which one-third of the population lived in 2007.

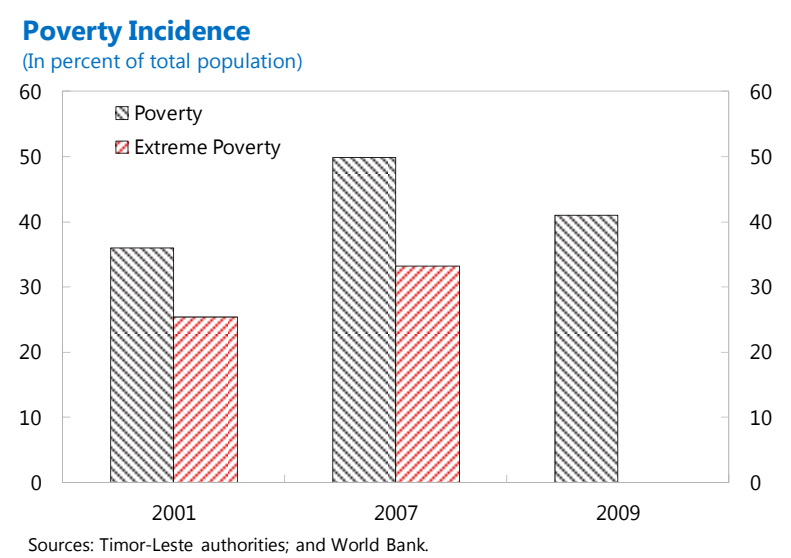

Public Expenditure

(In millions of U.S. dollars)

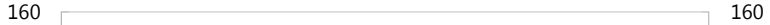

140 『 Health $\square-140$

\begin{tabular}{l|l|l}
140 & Q Education & 140 \\
120 &
\end{tabular}

\begin{tabular}{l|l|l|}
$n-100$ & $\square$ Social Protection
\end{tabular}

\begin{tabular}{c|c|c|}
100 & -100 \\
80 & 80
\end{tabular}

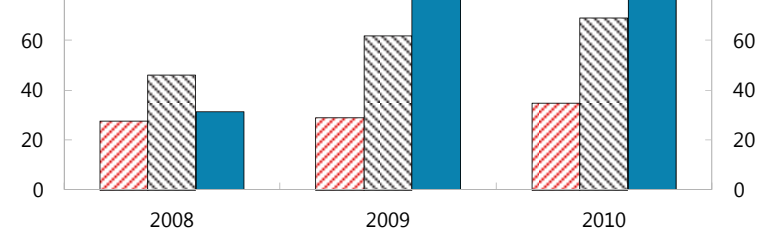

Source: Timor-Leste authorities.
Rural poverty (52 percent) is higher than urban poverty (45 percent) according to the 2007 estimates, owing to low agricultural productivity and limited access to roads. Poverty incidence also varies widely among regions; the Central region's poverty rate (58 percent) is more than double that of the Eastern region (27 percent).

Food security is one of the key elements in poverty reduction in Timor-Leste. Subsistence farming is the main source of livelihood for 75 percent of the population. About one-fourth of the population lived in hunger in 2010. 70 percent experienced food shortages in 2007, and the agricultural production data indicate that little progress has probably been made in recent years. Food shortage usually occurs for at least 2-3 months before the maize and rice harvest. Although food imports could address the shortage, poor roads and transportation systems are the major constraints to food supply to rural areas.

Improving food security and reducing poverty are integral parts of the Millennium Development Goals (MDGs) for Timor-Leste. The government aims to develop the agriculture sector to reduce rural poverty, achieve food security by 2020, and promote economic growth in rural areas. Following India's "green revolution" model, it has focused on providing high yielding seeds and fertilizers and improving irrigation.

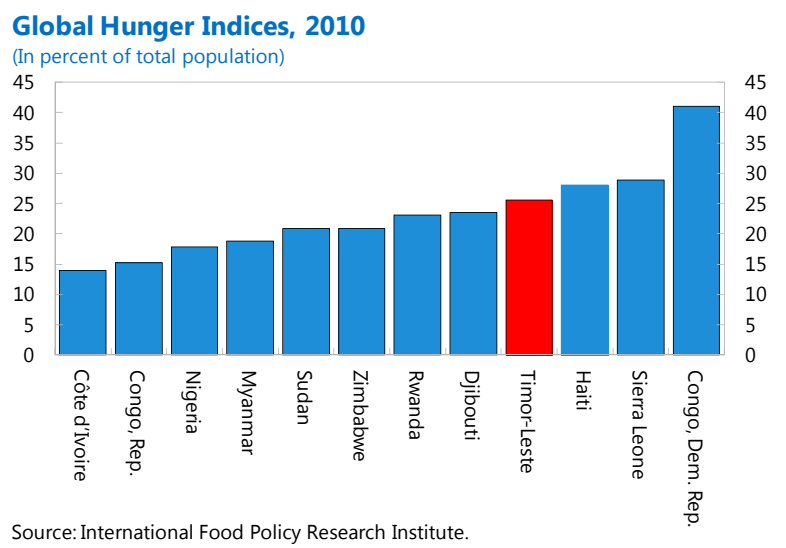

${ }^{1}$ In the absence of an updated living standards survey, the 2009 poverty estimate is derived using an econometric model and the 2009/10 demographic and health survey results. 
new investment projects, to reduce inflationary pressures. They agreed that the challenge faced by Timor-Leste is to utilize petroleum earnings in a way that avoids "resource curse" problems, including excessive real currency appreciation ("Dutch Disease"), to sustain strong economic growth over the long term.

\section{The authorities noted that to bring} the non-oil fiscal balance back in line with the ESI over the next 10 years, they plan to strengthen the MTBF to highlight the longer-term impact of the current fiscal stance and new spending initiatives. The MTBF will also include the government's strategy of private-sector-led growth to reduce its dependence on petroleum revenue. Costing of planned major projects is underway. The authorities indicated that the full costs and related recurrent costs will be incorporated in the MTBF once they are available. The authorities plan to review the recent FAD mission's recommendations to raise domestic revenue over the medium term. They also noted that Timor-Leste has many other

\section{B. Financial Sector Policy}

\section{Financial sector development. Staff}

advised that continued progress in developing the financial sector and strengthening the credit culture are critical for sustained growth in the private sector. The new commercial bank mineral resources such as copper and iron ore, which will provide additional fiscal revenue in the period ahead and that geological mapping is underway.

\section{The authorities stressed their} commitment to transparency. They noted the importance of transparency in Timor-Leste as a tool to prevent mismanagement and corruption as governmental institutions and legal frameworks are still being built. As the co-chair of the G7+ Group of Fragile and Conflict Affected States, the authorities plan to share their transparency model and experience with other fragile states.

26. The authorities noted that, although the government does not face financing constraints, loans from development banks to finance projects would help build their capacity to appraise and plan projects. They stated that any borrowing would substitute, not complement, withdrawals from the PF and that they are studying the pros and cons of PPPs, given substantial fiscal costs incurred in other countries.

plans to start mobile banking services soon to provide financial services to rural areas. To expand financial services further, infrastructure bottlenecks such as telecommunications need to be addressed. The public credit registry 
information system continues to improve, with an increasing number of borrowers in the database. The system could cover other nonbank lending institutions when they are ready to join it. Speeding up passage of key legislation would help financial sector development. In particular, the land law that parliament plans to discuss soon should help clarify property rights. In addition, contract enforcement needs to be improved by judicial reform to allow effective collateralization of loans and help expand private sector credit.

\section{Financial supervision. Staff welcomed} the Central Bank's efforts to strengthen financial supervision and regulation. The Central Bank has started conducting on- and off-site bank supervision and plans to strengthen coordination with foreign banks' home supervisors. It recently issued a regulation to provide a framework for other deposit-taking institutions such as microfinance institutions. A law on anti-money laundering and combating the financing of terrorism (AML/CFT) was submitted to Parliament, and after passage of the law, a financial intelligence unit (FIU) is expected to be established.

\section{Authorities' Views}

\section{The authorities broadly agreed with} staff's views. They indicated that the Central Bank will need continued TA in many areas, including for payments system and financial sector development.

\section{Exchange Rate and External Stability}

\section{Exchange rate regime. Staff}

supported the authorities' intention to continue to use the U.S. dollar as its currency. Given the country's limited capacity for independent monetary and exchange rate policies, the use of the U.S. dollar is appropriate and has provided a nominal anchor. There are no plans to change the exchange rate regime in the medium term, but as indicated in the SDP, the Central Bank plans to study, by 2015, the merits of adopting Timor-Leste's own currency.
31. External stability. The real effective exchange rate has appreciated by 6 percent in 2011. However, non-oil exports, excluding coffee, are minimal and the country depends highly on imports given almost no domestic production base except subsistence farming and coffee. The current account surplus is high but is projected to decline with rising government spending. The surplus is expected to remain below its sustainable level, computed as the difference between petroleum income and the ESI (text figure). 
Prudent fiscal policy will be key to maintaining external stability over the long term. A standard exchange rate assessment is not feasible because of a lack of data.

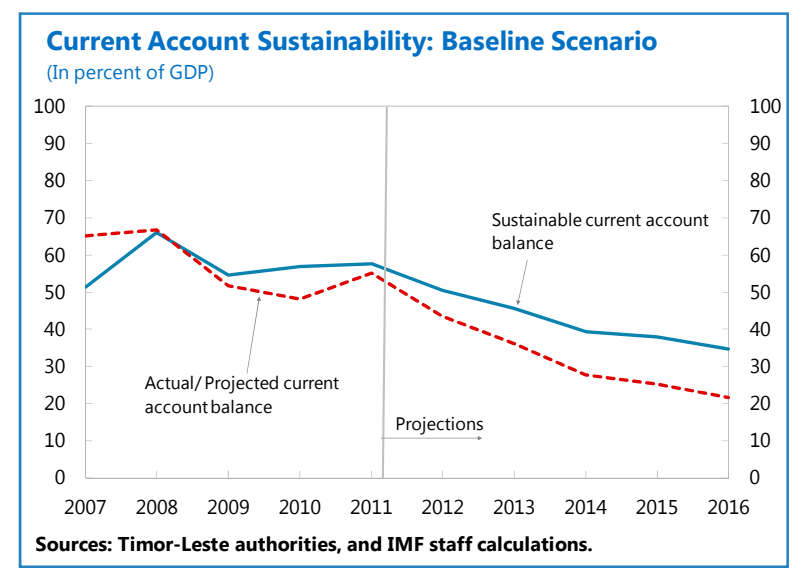

32. Competitiveness. Despite the government's efforts, Timor-Leste's business climate has improved little and remains among the least favorable of countries covered in recent surveys (text table). While political and security risks have fallen after the 2006 conflict, the most unfavorable factors include underdeveloped infrastructure, access to financing, and a low skill base. The ongoing structural reforms such as judicial reform and introduction of the land law will help the country improve its competitiveness.

\begin{tabular}{|c|c|c|c|c|c|}
\hline \multicolumn{6}{|c|}{ Assessment of Business Climate, 2010-11 } \\
\hline \multicolumn{3}{|c|}{ Doing Business 1/ } & \multicolumn{3}{|c|}{ Global Competitiveness Index } \\
\hline \multirow{4}{*}{ Countries } & Rank & Rank & \multirow{4}{*}{ Countries } & Rank & Rank \\
\hline & Among & Among & & Among & Among \\
\hline & 183 & 183 & & 142 & 139 \\
\hline & $(2011)$ & $(2010)$ & & $(2011)$ & $(2010)$ \\
\hline Bangladesh & 107 & 119 & Bangladesh & 108 & 107 \\
\hline Botswana & 52 & 45 & Botswana & 80 & 76 \\
\hline Cambodia & 147 & 145 & Cambodia & 97 & 109 \\
\hline Indonesia & 121 & 122 & Indonesia & 46 & 44 \\
\hline Nepal & 116 & 123 & Nepal & 125 & 130 \\
\hline Papua New Guinea & 103 & 102 & Philippines & 75 & 85 \\
\hline Philippines & 148 & 144 & Sri Lanka & 52 & 62 \\
\hline Sri Lanka & 102 & 105 & Thailand & 39 & 38 \\
\hline Timor-Leste & 174 & 164 & Timor-Leste & 131 & 133 \\
\hline Vietnam & 78 & 93 & Vietnam & 65 & 59 \\
\hline $\begin{array}{l}\text { Sources: World Ban } \\
1 \text { There are some } \\
2010 \text { reports, due to }\end{array}$ & Vorld De & $\begin{array}{l}\text { velopmen } \\
\text { s on the } \\
\text { ment in } \mathrm{m}\end{array}$ & $\begin{array}{l}\text { icators; and } \\
\text { ranking betw } \\
\text { dology. }\end{array}$ & Economic & $\begin{array}{l}\text { c Forum } \\
\text { ind the }\end{array}$ \\
\hline
\end{tabular}

\section{Other Issues}

\section{Statistics. Staff welcomed the} authorities' continued efforts to improve data quality and availability. The national accounts advisor, with IMF assistance, is finalizing compilation of the national accounts statistics for 2004-10 for the first time. Staff supported the decision to hand over the responsibility of national accounts compilation to the Statistical Office from the MOF's Macroeconomic Directorate. Data shortcomings remain and more staff and training will be needed to improve the data necessary for policy analysis and formulation. The authorities plan to update the CPI basket weights and improve price data collection. The agriculture survey needs to be improved, coordinated by the Statistical Office, together with the Ministry of Agriculture and FAO. The planned TA to improve trade data, and participation in the General Data Dissemination System would 
help the authorities upgrade macroeconomic statistics.

34. Technical assistance. Since 1999, Timor-Leste has been one of the largest recipients of Fund TA. It has focused on establishing key economic institutions for macroeconomic management, as well as on developing local capacity to manage them.

\section{STAFF APPRAISAL}

\section{Rising government spending has} supported strong economic growth, but inflation has jumped to double digits. Using its petroleum wealth, the government has resolved to step up development by scaling up investment in infrastructure. Real non-oil GDP growth is projected to remain strong at about 10 percent in 2012 and over the medium term. Key risks to the outlook are oil price volatility and the possibility that inflation continues to rise on the back of large increases in government spending.

\section{Given development needs,} investment in infrastructure is welcome, but the planned increase of spending over the next few years needs to be slowed to better align with the absorptive capacity of the economy and administrative constraints.

Continued large increases in government spending would raise inflationary pressure
There are still many areas where Timor-Leste needs further extensive TA. To manage its petroleum wealth, Timor-Leste is receiving TA under the Managing Natural Resource Wealth Topical Trust Fund. In addition to planned TA on statistics and PF asset management, two resident advisors for Treasury and PF management will be extended at the authorities' requests.

further, and high inflation will impose significant costs on the poor. In the absence of monetary policy, sound fiscal policy is key to containing high inflation and sustaining strong economic growth. The government's intention to consider adjusting the pace of 2012 budget execution if inflation remains high is welcome. Staff stressed the importance of continued progress in improving the capacity to implement capital projects.

\section{The authorities' plan to reduce the} non-oil fiscal deficit to a sustainable level over the next $\mathbf{1 0}$ years is appropriate. This will provide an important anchor for fiscal policy. To achieve this goal, the government may need to take substantial measures, including containing spending growth and increasing domestic revenue. In addition, the medium-term budget framework needs to be strengthened by including the full costs of 
planned major projects and recurrent costs once they are available. The authorities' intention to review the recent FAD mission's recommendations to raise non-oil revenue, including the introduction of a VAT over the medium term, is welcome. Repealing the very generous tax holidays under a new private investment law is recommended.

\section{The government has made solid} progress in improving public financial management. A well-managed Petroleum Fund is in place. Further progress has been made in addressing the weaknesses in PFM by establishing new institutions to strengthen public investment management. The lack of skilled personnel is the key constraint to PFM so the government's focus on training Timorese should help build capacity.

\section{Developing the financial sector and} strengthening the credit culture are critical for sustained growth in the private sector.

The Central Bank's continued efforts to strengthen financial sector supervision and regulations are welcome. Banks tightened their lending standards and improved credit assessments. Speeding up the passage of key legislations such as the land law would help financial sector development.

\section{The use of the U.S. dollar is} appropriate given the limited capacity for independent monetary and exchange rate policies. Non-oil exports, excluding coffee, are minimal and the country depends highly on imports. Accelerating structural reforms is needed to improve competitiveness. Prudent fiscal policy will be key to maintaining external stability over the long term.

\section{Data quality and availability need to} be improved. More staff and training are needed to improve the data necessary for policy analysis and formulation.

42. Staff recommends the next Article IV consultation be held on the standard 12month cycle. 
Figure 1. Timor-Leste: Macroeconomic Developments

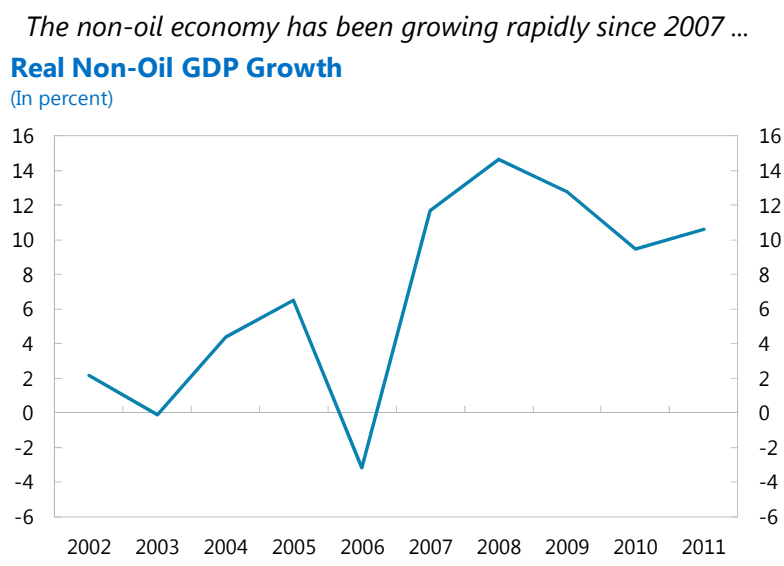

... rising oil exports earnings.

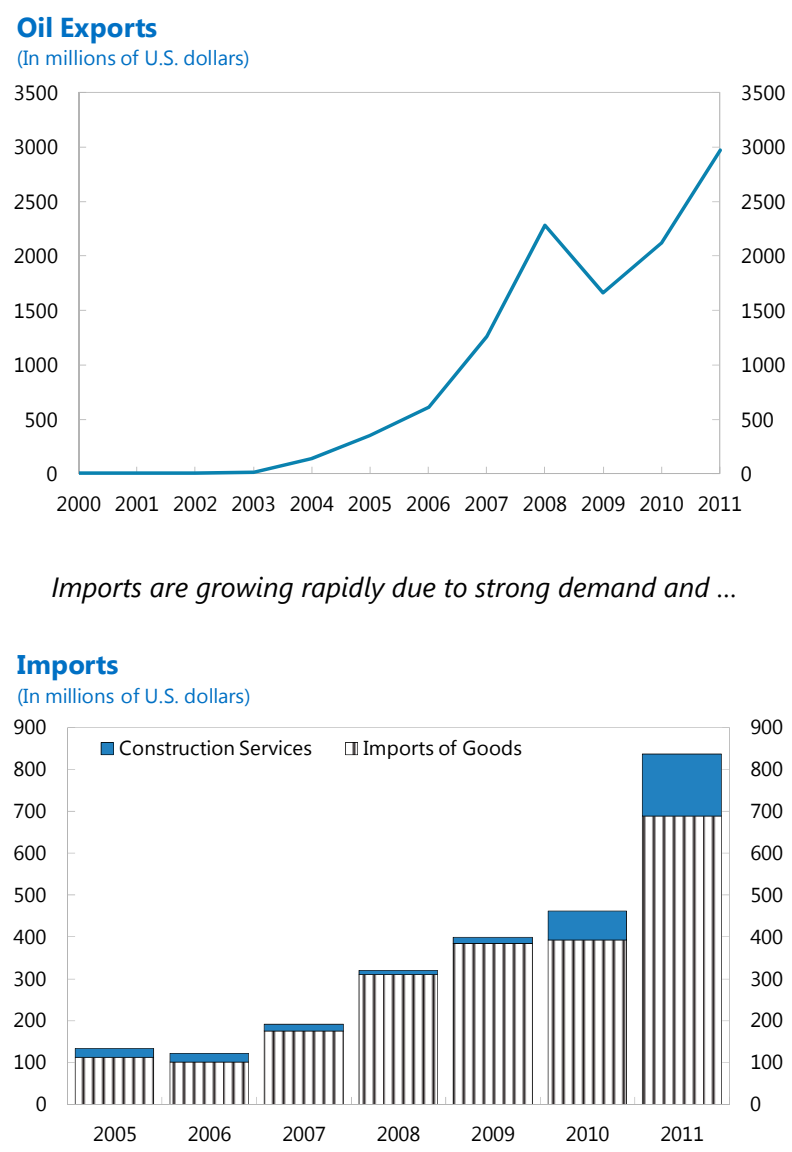

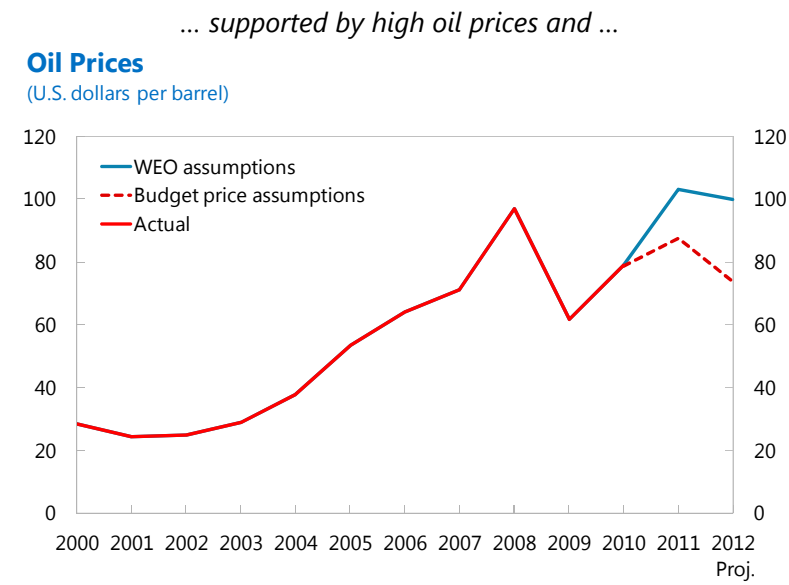

Non-oil exports are also picking up, driven by an all-time high coffee price.

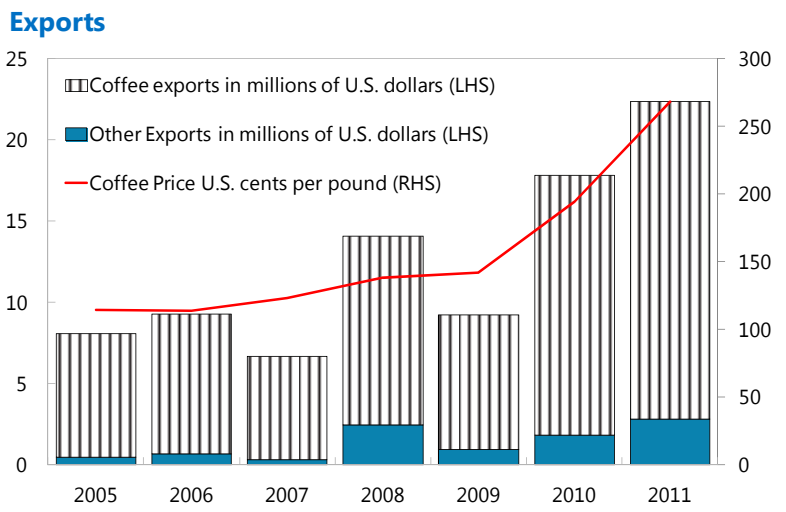

... inflation is also rising rapidly to over 10 percent, due to high food prices and strong demand.

Consumer Price Index in Dili

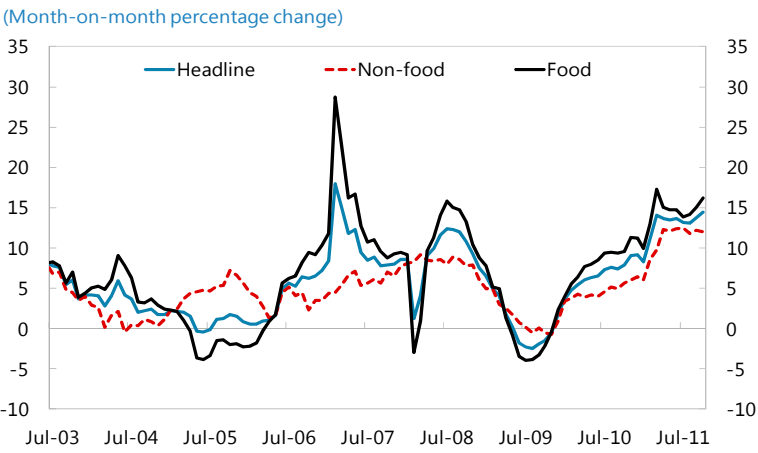

Sources: Timor-Leste authorities; INS; and IMF staff estimates. 


\section{Figure 2. Timor-Leste: Policy Developments}

The overall fiscal balance is in large surplus in recent years...

Expenditure and Petroluem Revenue (In millions of U.S. dollars)

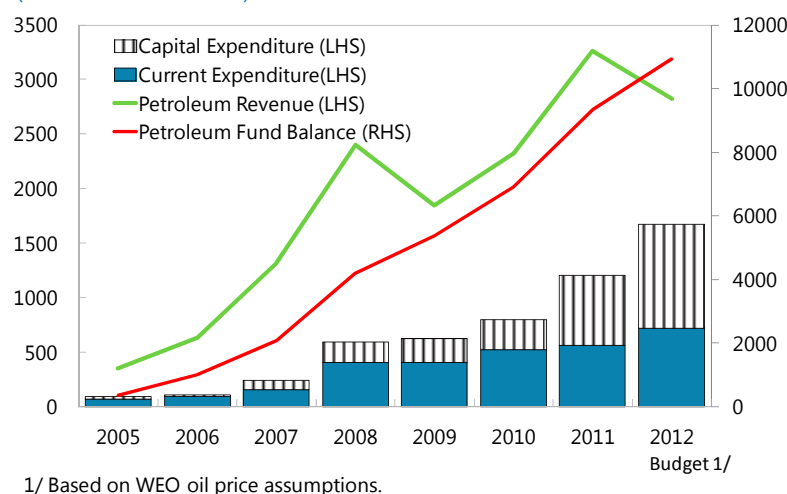

Non-oil government revenue is very small, but on the back of large oil revenue ...

\section{Revenue}

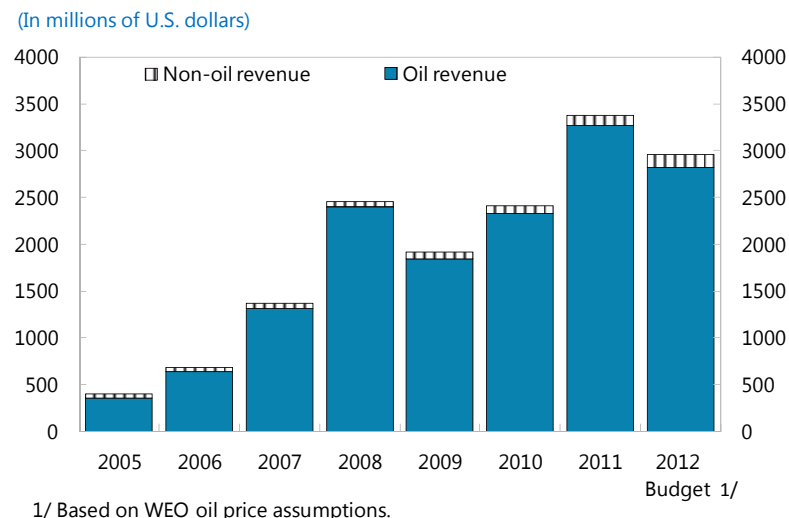

1/ Based on WEO oil price assumptions.

High inflation has driven up the REER despite the depreciation of the U.S. dollar.

\section{Exchange Rates}

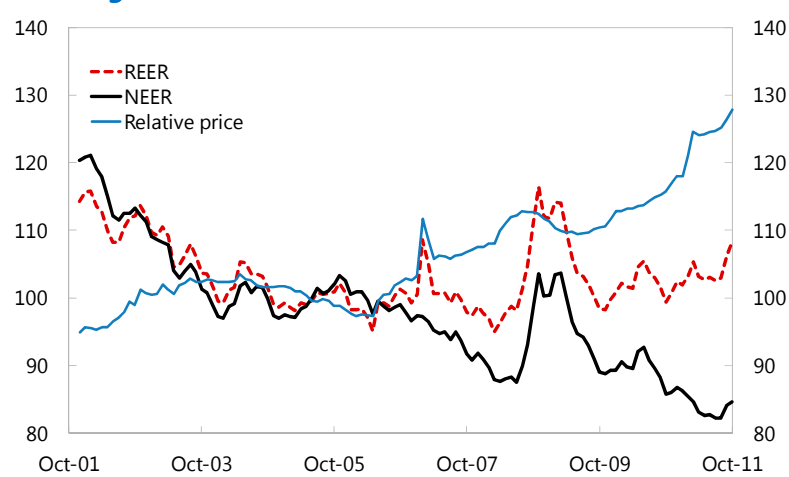

... resulting in large increases in the Petroleum Fund.

Petroleum Fund Balance

(In billions of U.S. dollars)

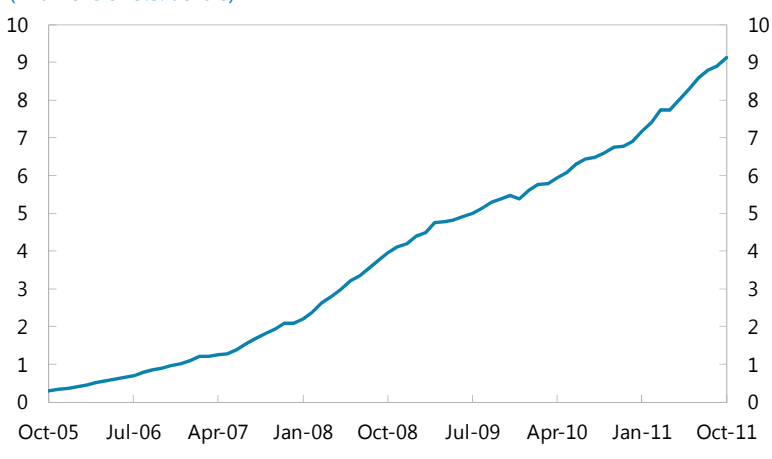

... government capital spending is growing fast.

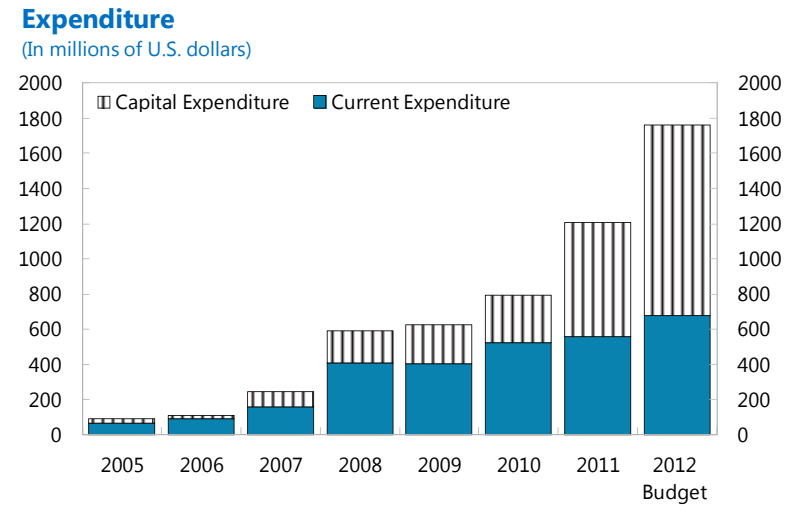

Credit to the private sector has started rising after being stagnant for a few years.

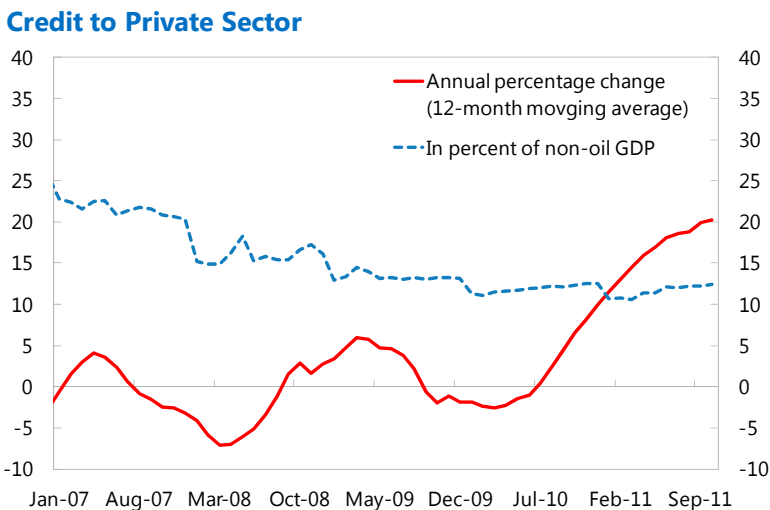

Sources: Timor-Leste authorities; INS; and IMF staff estimates. 


\section{Figure 3. Timor-Leste: Cross-Country Perspective}

Government spending in Timor-Leste stands out relative to other resource dependent economies.

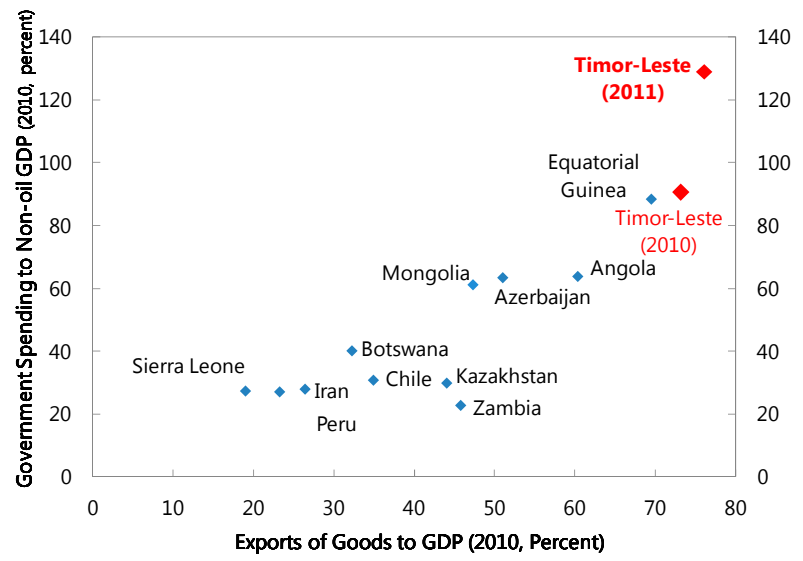

Timor-Leste had not experienced large real exchange appreciation until recently, but ...

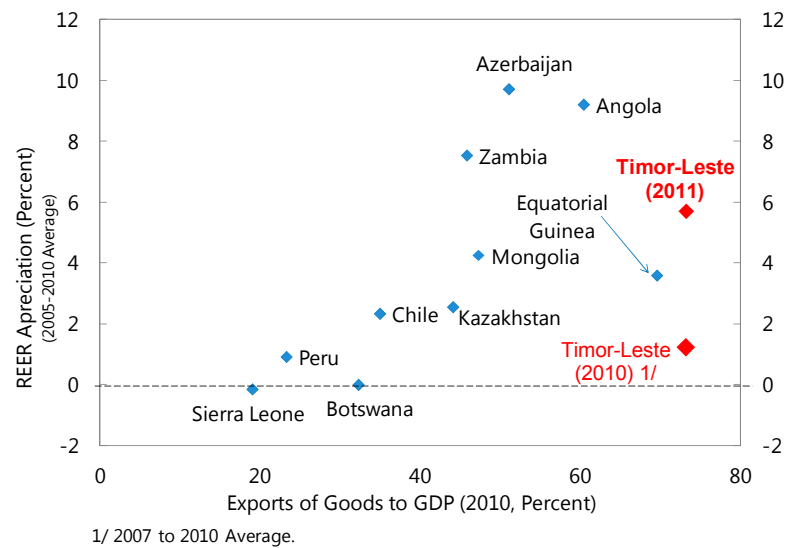

Per-capita income growth in Timor-Leste has been higher than in many other resource dependent economies...

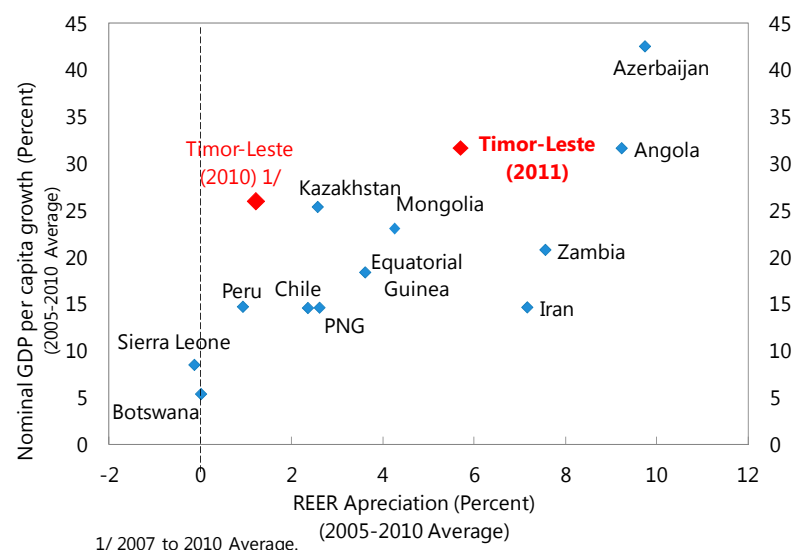

...and Timor-Leste's dependence on imports is going up.

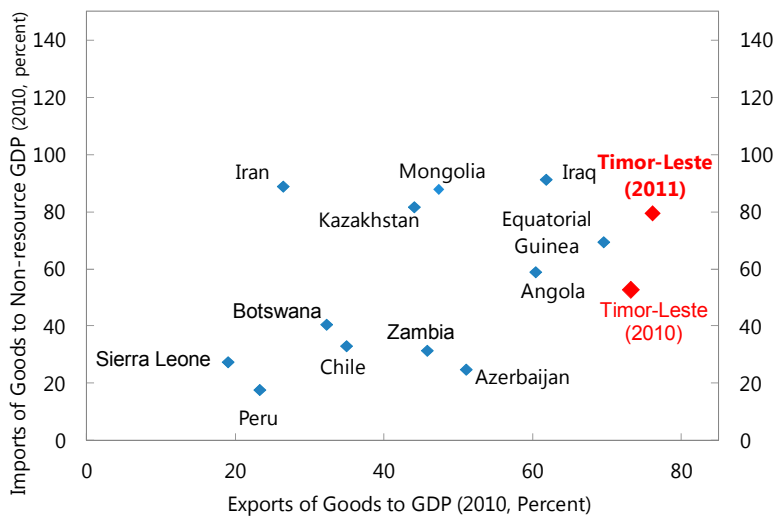

... high inflation in 2011 resulted in large real exchange appreciation.

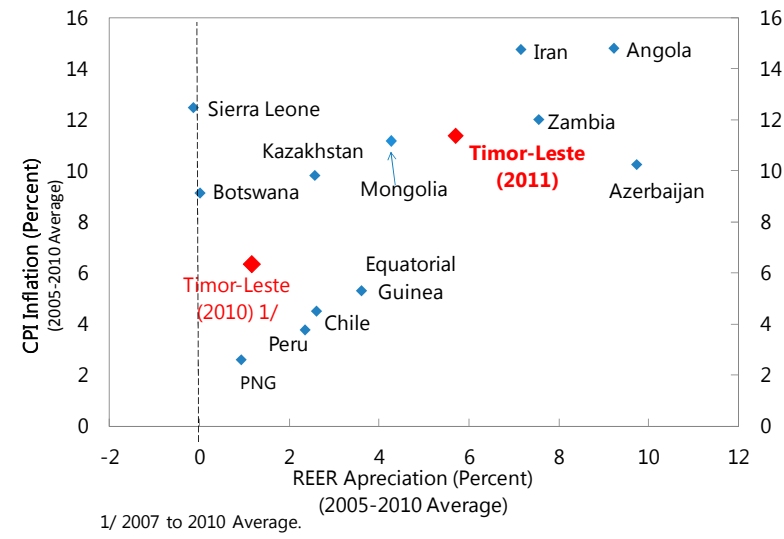

... but income per capita in Timor-Leste remains on the low side for resource dependent economies.

\section{GDP per Capita}

(2010, in thousands of U.S. dollars)

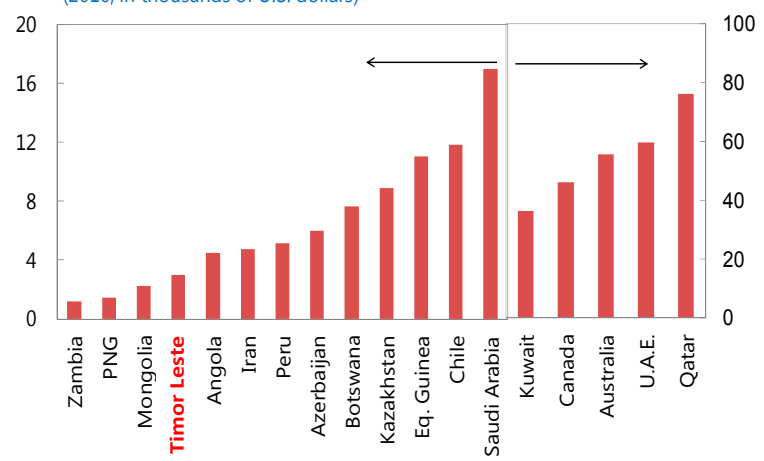

Sources: WEO database; APD LISC database; and IMF staff estimates. 
Table 1. Timor-Leste: Selected Economic and Financial Indicators, 2007-12

\begin{tabular}{|c|c|c|c|c|c|c|}
\hline $\begin{array}{ll}\text { GDP at current prices (2010): } & \text { US } \$ 3.2 \text { billion } \\
\text { Population (2010): } & 1.1 \text { million } \\
\text { GDP per capita (2010): } & \text { US } \$ 2,908 \\
\text { Non-oil GDP per capita (2010): US } \$ 821 \\
\text { Quota: SDR } 8.2 \text { million }\end{array}$ & & & & & & \\
\hline & 2007 & 2008 & 2009 & 2010 & 2011 & 2012 \\
\hline & & & & & Proj. & Proj. 1/ \\
\hline & & & nual pe & t chang & & \\
\hline Real sector & & & & & & \\
\hline Real non-oil GDP growth & 11.7 & 14.6 & 12.8 & 9.5 & 10.6 & 10.0 \\
\hline CPI (annual average) 2/ & 10.3 & 9.0 & 0.7 & 6.8 & 13.1 & 8.0 \\
\hline CPI (end-period) 2/ & 8.6 & 7.5 & 1.7 & 9.2 & 13.1 & 8.0 \\
\hline & & ercent & DP, unl & otherwi & ndicated & \\
\hline Central government operations & & & & & & \\
\hline Revenue & 75.4 & 80.8 & 72.5 & 75.2 & 78.1 & 72.6 \\
\hline Domestic revenue & 2.7 & 1.7 & 2.5 & 2.6 & 2.6 & 3.3 \\
\hline Petroleum revenue & 72.6 & 79.1 & 70.0 & 72.6 & 75.6 & 69.3 \\
\hline Expenditure & 13.5 & 19.6 & 23.8 & 24.8 & 28.0 & 34.8 \\
\hline Recurrent expenditure & 8.8 & 13.5 & 15.4 & 16.5 & 13.0 & 16.7 \\
\hline Capital expenditure & 4.8 & 6.1 & 8.4 & 8.4 & 15.0 & 18.1 \\
\hline Overall balance & 61.8 & 61.2 & 48.7 & 50.4 & 50.2 & 37.9 \\
\hline Non-oil overall balance (in percent of non-oil GDP) & -39.6 & -85.3 & -71.1 & -81.1 & -104.0 & -102.2 \\
\hline & (Anr & I percer & hange, & ss othe & e indica & \\
\hline Money and credit & & & & & & \\
\hline Deposits 3/ & 44.2 & 34.9 & 38.7 & 9.8 & 14.2 & $\ldots$ \\
\hline Credit to the private sector $3 /$ & -9.8 & 1.9 & 1.1 & 5.9 & 23.6 & $\ldots$ \\
\hline Lending interest rate (percent) $3 /$ & 15.0 & 13.1 & 11.2 & 11.0 & 10.8 & $\ldots$ \\
\hline & (In $\mathrm{m}$ & ns of $U$ & dollars, & ess oth & se indic & \\
\hline Balance of payments & & & & & & \\
\hline Current account balance & 1177 & 2023 & 1363 & 1538 & 2375 & 1773 \\
\hline (In percent of GDP) & 65.1 & 66.7 & 51.7 & 48.1 & 55.0 & 43.5 \\
\hline Trade balance & -169 & -297 & -376 & -374 & -666 & -795 \\
\hline Exports 4/ & 7 & 14 & 9 & 18 & 22 & 33 \\
\hline Imports & 176 & 311 & 385 & 392 & 689 & 829 \\
\hline Petroleum revenue & 1313 & 2400 & 1845 & 2323 & 3261 & 2821 \\
\hline Overall balance & 147 & -20 & 39 & 156 & -3 & 160 \\
\hline Public foreign assets (end-period) $3 / 5 /$ & 2316 & 4407 & 5627 & 7310 & 9743 & 11487 \\
\hline (In months of imports) & 158 & 170 & 175 & 224 & 170 & 166 \\
\hline Exchange rates & & & & & & \\
\hline NEER ( $2000=100$, period average) $3 /$ & 94.4 & 92.1 & 95.4 & 89.3 & 83.8 & $\ldots$ \\
\hline REER $(2000=100$, period average $) 3 /$ & 100.9 & 102.3 & 105.1 & 102.3 & 103.9 & $\ldots$ \\
\hline NEER $(2000=100$, end-period) $3 /$ & 91.8 & 100.3 & 89.3 & 86.7 & 84.7 & $\ldots$ \\
\hline REER (2000=100, end-period) $3 /$ & 98.7 & 112.0 & 99.8 & 102.4 & 108.2 & $\ldots$ \\
\hline Memorandum items: & & & & & & \\
\hline GDP at current prices: & 1808 & 3035 & 2634 & 3199 & 4315 & 4073 \\
\hline Non-oil GDP 6/ & 494 & 635 & 790 & 876 & 1054 & 1252 \\
\hline Oil GDP $7 /$ & 1313 & 2400 & 1845 & 2323 & 3261 & 2821 \\
\hline Crude oil prices (U.S. dollars per barrel, WEO) $8 /$ & 71 & 97 & 62 & 79 & 104 & 100 \\
\hline Petroleum Fund balance (in millions of U.S. dollars) 3/ & 2086 & 4197 & 5377 & 6904 & 9338 & 10923 \\
\hline Petroleum Fund balance (in percent of non-oil GDP) 3/ & 422 & 661 & 681 & 788 & 886 & 872 \\
\hline Public debt (in millions of U.S. dollars) & 0 & 0 & 0 & 0 & 0 & 43 \\
\hline
\end{tabular}

Sources: Timor-Leste authorities; and IMF staff estimates and projections.

1 / Staff proposals.

2/ For Dili (capital city). The countrywide CPI is available on a quarterly basis only.

$3 /$ Data for 2011 is as of end-October.

4/ Excludes petroleum exports, the income of which is recorded under the income account.

$5 /$ Includes Petroleum Fund balance and the central bank's official reserves.

$6 /$ Based on the resident national accounts advisor's new estimates.

7/ Petroleum revenue is used as a proxy for oil GDP.

8/ September 2011 WEO assumptions. 
Table 2. Timor-Leste: Summary Operations of the Central Government, 2008-16

\begin{tabular}{|c|c|c|c|c|c|c|c|c|c|c|c|}
\hline & \multirow[t]{2}{*}{2008} & \multirow[t]{2}{*}{2009} & \multirow[t]{2}{*}{2010} & \multicolumn{2}{|c|}{2011} & \multicolumn{2}{|c|}{2012} & 2013 & 2014 & 2015 & 2016 \\
\hline & & & & Budget & Proj. & Budget & Proj. 1/ & \multicolumn{4}{|c|}{ Projections $1 /$} \\
\hline & \multicolumn{11}{|c|}{ (In millions of U.S. Dollars, unless otherwise indicated) } \\
\hline Revenue & 2453.0 & 1910.5 & 2407.2 & 2940.0 & 3372.3 & 2225.9 & 2957.4 & 2832.8 & 2608.4 & 2748.2 & 2771.7 \\
\hline Petroleum revenue & 2400.2 & 1844.7 & 2323.4 & 2829.5 & 3261.5 & 2089.9 & 2821.3 & 2674.1 & 2422.9 & 2530.3 & 2515.3 \\
\hline Domestic revenue & 52.8 & 65.8 & 83.7 & 110.4 & 110.8 & 136.1 & 136.1 & 158.7 & 185.5 & 217.9 & 256.3 \\
\hline Expenditure & 594.2 & 627.0 & 794.2 & 1307.9 & 1206.4 & 1763.4 & 1415.6 & 1538.9 & 1646.6 & 1753.6 & 1858.8 \\
\hline Expense & 409.8 & 405.4 & 526.5 & 588.4 & 559.0 & 679.0 & 679.0 & 710.0 & 741.9 & 775.0 & 804.3 \\
\hline Net acquisition of non-financial assets & 184.4 & 221.7 & 267.7 & 719.5 & 647.4 & 1084.4 & 736.6 & 828.9 & 904.7 & 978.6 & 1054.5 \\
\hline Overall balance (Net lending (+)/borrowing (-)) & 1858.8 & 1283.4 & 1612.9 & 1632.1 & 2165.9 & 462.6 & 1541.8 & 1293.9 & 961.8 & 994.6 & 912.9 \\
\hline Non-oil overall balance & -541.4 & -561.2 & -710.5 & -1197.5 & -1095.6 & -1627.3 & -1279.5 & -1380.2 & -1461.1 & -1535.8 & -1602.5 \\
\hline \multicolumn{12}{|l|}{ CASH FLOWS FROM FINANCING ACTIVITIES: } \\
\hline Net acquisition of financial assets & 2026.5 & 1298.9 & 1658.5 & 1632.1 & 2165.9 & 495.7 & 1584.9 & 1374.1 & 1042.9 & 1097.4 & 1092.9 \\
\hline \multirow[t]{2}{*}{ Net incurrence of liabilities } & 0.0 & 0.0 & 0.0 & 0.0 & 0.0 & 33.1 & 43.1 & 80.2 & 81.1 & 102.8 & 180.0 \\
\hline & \multicolumn{11}{|c|}{ (In percent of GDP) } \\
\hline Revenue & 80.8 & 72.5 & 75.2 & 68.1 & 78.1 & 54.6 & 72.6 & 68.1 & 62.3 & 59.4 & 55.3 \\
\hline Taxes & 1.3 & 1.8 & 1.6 & 1.5 & 1.4 & 2.3 & 2.3 & 2.6 & 2.9 & 2.9 & 3.0 \\
\hline Taxes on income, profits, and capital gains & 0.6 & 0.6 & 0.6 & 0.5 & 0.5 & 1.0 & 1.0 & 1.0 & 1.1 & 1.1 & 1.1 \\
\hline Taxes on goods $\&$ services & 0.5 & 0.9 & 0.8 & 0.8 & 0.7 & 1.1 & 1.1 & 1.2 & 1.4 & 1.5 & 1.5 \\
\hline Taxes on international trade $\&$ transactions & 0.1 & 0.2 & 0.2 & 0.2 & 0.2 & 0.3 & 0.3 & 0.3 & 0.4 & 0.4 & 0.4 \\
\hline Petroleum revenue & 79.1 & 70.0 & 72.6 & 65.6 & 75.6 & 51.3 & 69.3 & 64.3 & 57.8 & 54.7 & 50.2 \\
\hline Other revenue & 0.5 & 0.7 & 1.0 & 1.1 & 1.1 & 1.0 & 1.0 & 1.2 & 1.5 & 1.8 & 2.1 \\
\hline Expenditure & 19.6 & 23.8 & 24.8 & 30.3 & 28.0 & 43.3 & 34.8 & 37.0 & 39.3 & 37.9 & 37.1 \\
\hline Expense & 13.5 & 15.4 & 16.5 & 13.6 & 13.0 & 16.7 & 16.7 & 17.1 & 17.7 & 16.7 & 16.1 \\
\hline Compensation of employees & 1.7 & 3.3 & 2.9 & 2.7 & 2.6 & 3.4 & 3.4 & 3.5 & 3.6 & 3.4 & 3.3 \\
\hline Purchases of goods and senvices & 7.0 & 8.1 & 7.6 & 6.8 & 6.5 & 8.5 & 8.5 & 8.7 & 9.1 & 8.6 & 8.2 \\
\hline Subsidies/Social Benefits & 4.8 & 4.0 & 6.0 & 4.1 & 3.9 & 4.8 & 4.8 & 4.9 & 5.0 & 4.7 & 4.5 \\
\hline Net acquisition of non-financial assets & 6.1 & 8.4 & 8.4 & 16.7 & 15.0 & 26.6 & 18.1 & 19.9 & 21.6 & 21.1 & 21.1 \\
\hline Gross operating balance & 67.3 & 57.1 & 58.8 & 54.5 & 65.2 & 38.0 & 55.9 & 51.0 & 44.5 & 42.6 & 39.3 \\
\hline Overall balance (Net lending (+)/borrowing $(-))$ & 61.2 & 48.7 & 50.4 & 37.8 & 50.2 & 11.4 & 37.9 & 31.1 & 23.0 & 21.5 & 18.2 \\
\hline \multicolumn{12}{|l|}{ CASH FLOWS FROM FINANCING ACTIVITIES: } \\
\hline Net acquisition of financial assets & 66.8 & 49.3 & 51.8 & 37.8 & 50.2 & 12.2 & 38.9 & 33.0 & 24.9 & 23.7 & 21.8 \\
\hline \multirow[t]{2}{*}{ Net incurrence of liabilities } & 0.0 & 0.0 & 0.0 & 0.0 & 0.0 & 0.8 & 1.1 & 1.9 & 1.9 & 2.2 & 3.6 \\
\hline & \multicolumn{11}{|c|}{ (In percent of non-oil GDP) } \\
\hline Revenue & 386.5 & 241.9 & 274.9 & 279.0 & 320.0 & 177.8 & 236.2 & 190.5 & 147.6 & 130.9 & 111.1 \\
\hline o/w Petroleum revenue & 378.2 & 233.6 & 265.3 & 268.5 & 309.5 & 166.9 & 225.3 & 179.8 & 137.1 & 120.5 & 100.9 \\
\hline Expenditure & 93.6 & 79.4 & 90.7 & 124.1 & 114.5 & 140.8 & 113.1 & 103.5 & 93.2 & 83.5 & 74.5 \\
\hline Expense (Recurrent expenditure) & 64.6 & 51.3 & 60.1 & 55.8 & 53.0 & 54.2 & 54.2 & 47.7 & 42.0 & 36.9 & 32.3 \\
\hline Net acquisition of non-financial assets (Capital expenditure) & 29.1 & 28.1 & 30.6 & 68.3 & 61.4 & 86.6 & 58.8 & 55.7 & 51.2 & 46.6 & 42.3 \\
\hline Non-oil overall balance & -85.3 & -71.1 & -81.1 & -113.6 & -104.0 & -130.0 & -102.2 & -92.8 & -82.7 & -73.2 & -64.3 \\
\hline \multicolumn{12}{|l|}{ Memorandum items: } \\
\hline Development Partner Commitments (in millions of U.S. dollars, grants) & 184.4 & 215.6 & 263.9 & 272.8 & 245.5 & 188.9 & 188.9 & 128.8 & 72.0 & 63.7 & 0.0 \\
\hline \multicolumn{12}{|l|}{ Rice operations (in millions of U.S. dollars): } \\
\hline Sales & 16.8 & 20.4 & 12.6 & 10.0 & 10.0 & 0.8 & 0.8 & 0.9 & 1.1 & 1.2 & 1.3 \\
\hline Purchases & 77.8 & 31.8 & 35.0 & 0.0 & 0.0 & 0.0 & 0.0 & 0.0 & 0.0 & 0.0 & 0.0 \\
\hline Education (in millions of U.S. dollars) & 45.9 & 61.7 & 68.8 & 85.0 & & 111.1 & & & & & \\
\hline Education (in percent of non-oil GDP) & 7.2 & 7.8 & 7.9 & 8.1 & & 8.9 & & & & & \\
\hline Health (in millions of U.S. dollars) & 27.6 & 28.9 & 34.6 & 40.5 & & 51.1 & & & & & \\
\hline Health (in percent of non-oil GDP) & 4.3 & 3.7 & 4.0 & 3.8 & & 4.1 & & & & & \\
\hline ESI (in percent of non-oil GDP) & 62.4 & 51.7 & 57.3 & 69.6 & 73.3 & 52.9 & 61.4 & 52.0 & 44.1 & 37.3 & 31.6 \\
\hline Withdrawals above ESI (in percent of non-oil GDP) & 0.0 & 13.2 & 35.3 & 18.6 & 5.2 & 74.5 & 37.3 & 35.4 & 34.0 & 30.9 & 25.4 \\
\hline Petroleum Fund balance & 138.3 & 204.1 & 215.8 & 204.0 & 216.4 & 228.2 & 268.2 & 295.5 & 318.4 & 311.8 & 310.0 \\
\hline Crude oil price (U.S. dollar per barrel) $2 /$ & & & & 87.7 & & 73.7 & & 75.7 & 78.6 & 81.6 & 84.7 \\
\hline Crude oil price (U.S. dollar per barrel, WEO) $3 /$ & 97.0 & 61.8 & 79.0 & & 104.2 & & 100.0 & 99.5 & 97.5 & 96.5 & 95.5 \\
\hline Non-oil GDP at current prices (in millions of U.S. dollars) & 635 & 790 & 876 & 1054 & 1054 & 1252 & 1252 & 1487 & 1767 & 2099 & 2494 \\
\hline GDP at current prices (in millions of U.S. dollars) & 3035 & 2634 & 3199 & 4315 & 4315 & 4073 & 4073 & 4161 & 4190 & 4630 & 5009 \\
\hline
\end{tabular}

Sources: Timor-Leste authorities; and IMF staff estimates.

1/ Staff proposals.

2/ Simple average of EIA's low case and reference prices.

3/ September 2011 WEO assumptions. 
Table 3. Timor-Leste: Monetary Developments, 2006-11

\begin{tabular}{|c|c|c|c|c|c|c|}
\hline & 2006 & 2007 & 2008 & 2009 & 2010 & $\frac{2011}{\text { Proj. }}$ \\
\hline & \multicolumn{6}{|c|}{ (In millions of U.S. dollars) } \\
\hline \multicolumn{7}{|l|}{ Banking system $1 /$} \\
\hline Net foreign assets $2 /$ & 113 & 318 & 393 & 443 & 622 & 558 \\
\hline Gross reserves & 84 & 230 & 210 & 250 & 406 & 368 \\
\hline Other foreign assets & 61 & 126 & 211 & 219 & 244 & 368 \\
\hline Foreign liabilities & 31 & 38 & 29 & 26 & 28 & 178 \\
\hline Net domestic assets & -13 & -174 & -200 & -174 & -327 & -210 \\
\hline Net credit to central government & -83 & -219 & -230 & -206 & -331 & -248 \\
\hline Net credit to state and local government & 0 & 0 & 0 & 0 & 0 & 0 \\
\hline Net credit to public nonfinancial corporations & 0 & 0 & 0 & 0 & 0 & 0 \\
\hline Credit to private sector & 111 & 101 & 102 & 104 & 110 & 136 \\
\hline Other items (net) & -42 & -56 & -73 & -72 & -105 & -97 \\
\hline Broad money & 100 & 144 & 193 & 268 & 295 & 348 \\
\hline Narrow money & 54 & 75 & 104 & 157 & 141 & 167 \\
\hline Currency in circulation 3/ & 2 & 2 & 2 & 3 & 3 & 4 \\
\hline Transferable deposits & 52 & 73 & 102 & 155 & 138 & 163 \\
\hline Other deposits & 46 & 68 & 88 & 111 & 154 & 181 \\
\hline \multicolumn{7}{|l|}{ Central Bank } \\
\hline Net foreign assets $2 l$ & 84 & 230 & 210 & 238 & 394 & 356 \\
\hline Gross reserves & 84 & 230 & 210 & 250 & 406 & 368 \\
\hline Foreign liabilities & 0 & 0 & 0 & 12 & 12 & 12 \\
\hline Net domestic assets & -76 & -210 & -185 & -182 & -340 & -293 \\
\hline Net credit to central government & -56 & -190 & -196 & -163 & -318 & -240 \\
\hline Net credit to other depository corporations & 1 & 1 & 42 & 2 & 24 & 8 \\
\hline Other items (net) & -20 & -20 & -31 & -21 & -45 & -61 \\
\hline Monetary Base & 8 & 20 & 26 & 56 & 55 & 63 \\
\hline Currency in circulation & 2 & 2 & 2 & 3 & 3 & 4 \\
\hline Other liabilities to depositary corporations & 6 & 18 & 23 & 53 & 51 & 59 \\
\hline
\end{tabular}

Memorandum items

Annual broad money growth

Annual reserve money growth

Annual credit to the private sector growth

Credit/non-oil GDP

Broad money/non-oil GDP

Credit/deposits

Nonperforming loans/total loans

Amounts of non-perfoming loans (in millions of U.S. dollars)

Loan rate 4/

Deposit rate 5/

(In percent, unless otherwise indicated)

$\begin{array}{rrrrrr}28.2 & 43.9 & 34.1 & 39.3 & 9.9 & 18.0 \\ 30.0 & 147.0 & 25.9 & 120.4 & -2.7 & 15.0 \\ 5.2 & -9.8 & 1.9 & 1.1 & 5.9 & 23.6 \\ 25.6 & 20.3 & 16.1 & 13.1 & 12.5 & 12.9 \\ 22.9 & 29.1 & 30.4 & 34.0 & 33.7 & 33.1 \\ 113.6 & 71.1 & 53.9 & 39.0 & 37.6 & 39.4 \\ 27.8 & 30.2 & 28.2 & 32.1 & 41.7 & \ldots \\ 25.6 & 30.3 & 29.7 & 35.6 & 46.3 & \ldots \\ 16.6 & 15.0 & 12.3 & 10.8 & 11.1 & \ldots \\ 1.0 & 1.0 & 1.1 & 1.1 & 1.1 & \ldots \\ & & & & & \end{array}$

Sources: Central Bank of Timor-Leste; and IMF staff estimates.

1/ Includes the Central Bank, three commercial banks (branches of foreign banks), and a micro-finance institution.

2/ An oil fund was created in September 2005 and the deposits were moved off-shore and onto the government balance sheet.

3/ Includes only coinage issued by the Central Bank. No data are available for notes due to dollarization of the financial system.

4/ Rate offered by other depository corporations on three-month time deposits in U.S. dollars. The rate is weighted by deposit amounts.

$5 /$ Rate charged by other depository corporations on loans in U.S. dollars. The rate is weighted by loan amounts. 
Table 4. Timor-Leste: Balance of Payments, 2008-16

\begin{tabular}{|c|c|c|c|c|c|c|c|c|c|}
\hline & 2008 & 2009 & 2010 & 2011 & 2012 & 2013 & 2014 & 2015 & 2016 \\
\hline & & & Prel. & Proj. & \multicolumn{5}{|c|}{ Projections } \\
\hline & \multicolumn{9}{|c|}{ (In millions of U.S. dollars) } \\
\hline Current account balance & 2,023 & 1,363 & 1,538 & 2,375 & 1,773 & 1,506 & 1,158 & 1,168 & 1,082 \\
\hline Trade balance & -297 & -376 & -374 & -666 & -795 & -861 & -909 & -976 & $-1,016$ \\
\hline Exports 1/ & 14 & 9 & 18 & 22 & 33 & 29 & 43 & 37 & 56 \\
\hline Of which: Coffee & 12 & 8 & 16 & 20 & 30 & 25 & 38 & 33 & 49 \\
\hline Imports & -311 & -385 & -392 & -689 & -829 & -890 & -952 & $-1,013$ & $-1,072$ \\
\hline Of which: Food & -45 & -50 & -42 & -52 & -52 & -53 & -54 & -56 & -57 \\
\hline Manufactured goods & -169 & -263 & -267 & -537 & -668 & -715 & -764 & -807 & -859 \\
\hline Services (net) & -444 & -505 & -607 & -690 & -641 & -548 & -449 & -469 & -498 \\
\hline Receipts & 44 & 47 & 69 & 93 & 103 & 97 & 92 & 107 & 126 \\
\hline Of which: Travel & 14 & 18 & 36 & 42 & 50 & 59 & 69 & 80 & 95 \\
\hline Payments & -488 & -552 & -676 & -782 & -744 & -645 & -541 & -576 & -624 \\
\hline Of which: UN and donor related & -398 & -417 & -445 & -446 & -362 & -215 & -72 & -64 & -64 \\
\hline Construction & -9 & -14 & -69 & -148 & -156 & -177 & -188 & -201 & -214 \\
\hline Income (net) & 2,407 & 1,846 & 2,171 & 3,284 & 2,847 & 2,699 & 2,443 & 2,548 & 2,532 \\
\hline Of which: Oil/gas receipts and interest & 2,400 & 1,845 & 2,323 & 3,261 & 2,821 & 2,674 & 2,423 & 2,530 & 2,515 \\
\hline Current transfers (net) & 357 & 399 & 348 & 446 & 363 & 216 & 72 & 64 & 64 \\
\hline Capital and financial accounts & $-2,041$ & $-1,263$ & $-1,280$ & $-2,377$ & $-1,614$ & $-1,354$ & $-1,011$ & $-1,027$ & -937 \\
\hline Official capital transfers & 17 & 27 & 31 & 35 & 30 & 21 & 13 & 9 & 4 \\
\hline Financial account & $-2,058$ & $-1,290$ & $-1,312$ & $-2,412$ & $-1,644$ & $-1,375$ & $-1,024$ & $-1,036$ & -941 \\
\hline Of which: Oil/gas savings & $-2,003$ & $-1,330$ & $-1,482$ & 2,461 & $-1,585$ & $-1,374$ & $-1,043$ & $-1,097$ & $-1,093$ \\
\hline FDI & 39 & 30 & 5 & 46 & 55 & 64 & 75 & 88 & 104 \\
\hline Errors and omissions (net) & -2 & -61 & -101 & 0 & 0 & 0 & 0 & 0 & 0 \\
\hline Overall balance & -20 & 39 & 156 & -3 & 160 & 151 & 146 & 140 & 146 \\
\hline Changes in official reserves (increase -) & 20 & -39 & -156 & 3 & -160 & -151 & -146 & -140 & -146 \\
\hline & \multicolumn{9}{|c|}{ (In percent of GDP) } \\
\hline Current account & 67 & 52 & 48 & 55 & 44 & 36 & 28 & 25 & 22 \\
\hline Trade balance & -10 & -14 & -12 & -15 & -20 & -21 & -22 & -21 & -20 \\
\hline Exports & 0 & 0 & 1 & 1 & 1 & 1 & 1 & 1 & 1 \\
\hline Imports & -10 & -15 & -12 & -16 & -20 & -21 & -23 & -22 & -21 \\
\hline Services (net) & -15 & -19 & -19 & -16 & -16 & -13 & -11 & -10 & -10 \\
\hline Income (net) & 79 & 70 & 68 & 76 & 70 & 65 & 58 & 55 & 51 \\
\hline Current transfers (net) & 12 & 15 & 11 & 10 & 9 & 5 & 2 & 1 & 1 \\
\hline Capital and financial accounts & -67 & -48 & -40 & -55 & -40 & -33 & -24 & -22 & -19 \\
\hline Overall balance & -1 & 1 & 5 & 0 & 4 & 4 & 3 & 3 & 3 \\
\hline & \multicolumn{9}{|c|}{ (In percent of non-oil GDP) } \\
\hline Current account & 319 & 173 & 176 & 225 & 142 & 101 & 66 & 56 & 43 \\
\hline Trade balance & -47 & -48 & -43 & -63 & -64 & -58 & -51 & -46 & -41 \\
\hline Exports & 2 & 1 & 2 & 2 & 3 & 2 & 2 & 2 & 2 \\
\hline Imports & -49 & -49 & -45 & -65 & -66 & -60 & -54 & -48 & -43 \\
\hline Services (net) & -70 & -64 & -69 & -65 & -51 & -37 & -25 & -22 & -20 \\
\hline Income (net) & 379 & 234 & 248 & 312 & 227 & 181 & 138 & 121 & 102 \\
\hline Current transfers (net) & 56 & 50 & 40 & 42 & 29 & 15 & 4 & 3 & 3 \\
\hline Capital and financial accounts & -322 & -160 & -146 & -226 & -129 & -91 & -57 & -49 & -38 \\
\hline Overall balance & -3 & 13 & 29 & 0 & 13 & 10 & 8 & 7 & 6 \\
\hline & \multicolumn{9}{|c|}{ (In millions of U.S. dollars, unless otherwise indicated) } \\
\hline \multicolumn{10}{|l|}{ Memorandum items: } \\
\hline Public foreign assets (end-period) & 4,407 & 5,627 & 7,310 & 9,743 & 11,487 & 13,013 & 14,202 & 15,440 & 16,678 \\
\hline Of which: Central bank reserves & 210 & 250 & 406 & 405 & 565 & 716 & 862 & 1,003 & 1,148 \\
\hline Petroleum Fund balance & 4,197 & 5,377 & 6,904 & 9,338 & 10,923 & 12,297 & 13,340 & 14,437 & 15,530 \\
\hline Non-oil GDP at current prices & 635 & 790 & 876 & 1,054 & 1,252 & 1,487 & 1,767 & 2,099 & 2,494 \\
\hline GDP at current prices & 3,035 & 2,634 & 3,199 & 4,315 & 4,073 & 4,161 & 4,190 & 4,630 & 5,009 \\
\hline Crude oil price (U.S. dollar per barrel, WEO) $2 /$ & 97 & 62 & 79 & 104 & 100 & 100 & 98 & 97 & 96 \\
\hline
\end{tabular}

Sources: Data provided by the Timor-Leste authorities, and IMF staff estimates.

$1 /$ Excludes petroleum exports, the income of which is recorded under the income account.

2/ September 2011 WEO assumptions. 
Table 5. Timor-Leste: Medium-Term Scenario, 2008-16

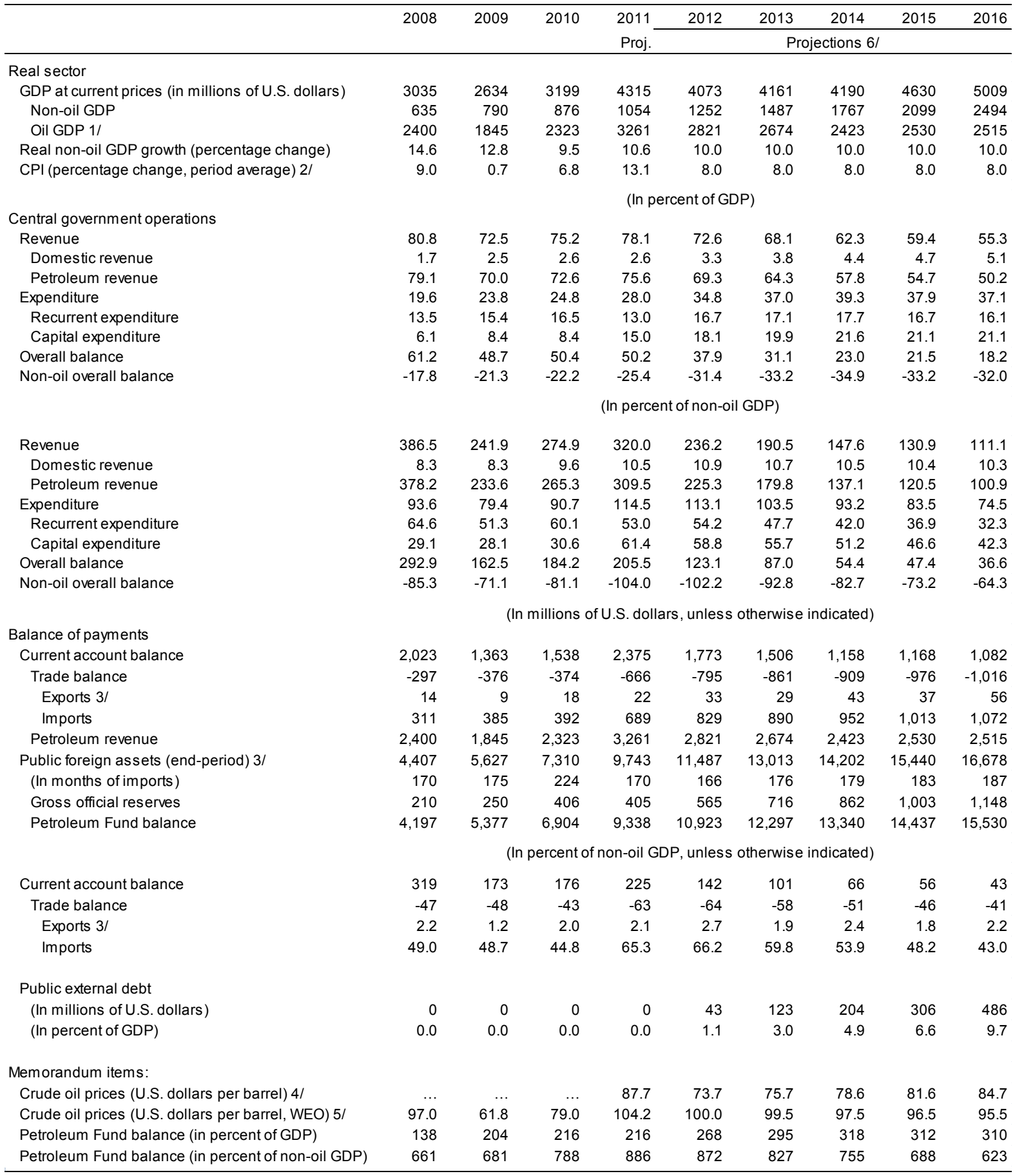

Sources: Timor-Leste authorities; and IMF staff estimates and projections.

1/ Petroleum revenue is used as a proxy for oil GDP.

2/ For Dili (capital city). The countrywide CPI is available on a quarterly basis only.

3/ Excludes petroleum exports, the income of which is recorded under the income account.

4/ A simple average of EIA's low case and reference prices for West Texas Intermediate (WTI) crude oil.

5/ A simple average of UK Brent, Dubai, and WTI crude oil prices; September 2011 WEO assumptions.

6/ Staff proposals. 


\begin{tabular}{|c|c|c|c|c|c|}
\hline & 1990 & 1995 & 2000 & 2005 & 2009 \\
\hline \multicolumn{6}{|l|}{ Goal 1: Eradicate extreme poverty and hunger } \\
\hline Employment to population ratio, $15+$, total (percent) & 67 & 67 & 65 & 68 & 68 \\
\hline Employment to population ratio, ages $15-24$, total (percent) & 53 & 53 & 51 & 59 & 60 \\
\hline Income share held by lowest 20 percent & $\ldots$ & $\ldots$ & 7 & 9 & 9 \\
\hline Malnutrition prevalence, weight for age (percent of children under 5) & $\ldots$ & $\ldots$ & 41 & 42 & $\ldots$ \\
\hline Poverty gap at $\$ 1.25$ a day (PPP) (percent) & $\ldots$ & $\ldots$ & 19 & 9 & 9 \\
\hline Poverty headcount ratio at $\$ 1.25$ a day (PPP) (percent of population) & $\ldots$ & $\ldots$ & 53 & 37 & 37 \\
\hline \multicolumn{6}{|l|}{ Goal 2: Achieve universal primary education } \\
\hline Primary completion rate, total (percent of relevant age group) & $\ldots$ & $\ldots$ & $\ldots$ & $\ldots$ & 80 \\
\hline Total enrollment, primary (percent net) & $\ldots$ & $\ldots$ & $\ldots$ & 69 & 83 \\
\hline \multicolumn{6}{|l|}{ Goal 3: Promote gender equality and empower women } \\
\hline Proportion of seats held by women in national parliaments (percent) & $\ldots$ & $\ldots$ & $\ldots$ & 25 & 29 \\
\hline Ratio of female to male primary enrollment (percent) & $\ldots$ & $\ldots$ & $\ldots$ & 92 & 95 \\
\hline Ratio of female to male secondary enrollment (percent) & $\ldots$ & $\ldots$ & $\ldots$ & 100 & $\ldots$ \\
\hline Ratio of female to male tertiary enrollment (percent) & $\ldots$ & $\ldots$ & 127 & $\ldots$ & 71 \\
\hline $\begin{array}{l}\text { Share of women employed in the nonagricultural sector } \\
\text { (percent of total nonagricultural employment) }\end{array}$ & $\ldots$ & $\ldots$ & 35.0 & $\ldots$ & $\ldots$ \\
\hline \multicolumn{6}{|l|}{ Goal 4: Reduce child mortality } \\
\hline Immunization, measles (percent of children ages $12-23$ months) & $\ldots$ & $\ldots$ & 56 & 48 & 68 \\
\hline Mortality rate, infant (per 1,000 live births) & 127 & 105 & 82 & 62 & 44 \\
\hline Mortality rate, under-5 (per 1,000$)$ & 169 & 137 & 104 & 76 & 64 \\
\hline \multicolumn{6}{|l|}{ Goal 5: Improve maternal health } \\
\hline Adolescent fertility rate (births per 1,000 women ages $15-19$ ) & $\ldots$ & 72 & 71 & 68 & 60 \\
\hline Births attended by skilled health staff (percent of total) & $\ldots$ & 26 & 24 & 18 & 30 \\
\hline Contraceptive prevalence (percent of women ages 15-49) & 25 & 23 & 8 & 20 & 22 \\
\hline Maternal mortality ratio (modeled estimate, per 100,000 live births) & 650 & 590 & 520 & 420 & 557 \\
\hline Pregnant women receiving prenatal care (percent) & $\ldots$ & $\ldots$ & 43 & 61 & $\ldots$ \\
\hline \multicolumn{6}{|l|}{ Goal 6: Combat HIV/AIDS, malaria, and other diseases } \\
\hline \multicolumn{6}{|l|}{ Children with fever receiving antimalarial drugs } \\
\hline (percent of children under age 5 with fever) & $\ldots$ & $\ldots$ & 47 & $\ldots$ & $\ldots$ \\
\hline Incidence of tuberculosis (per 100,000 people) & $\ldots$ & $\ldots$ & 498 & 498 & 498 \\
\hline Tuberculosis case detection rate (percent, all forms) & $\ldots$ & $\ldots$ & 64 & 76 & 84 \\
\hline \multicolumn{6}{|l|}{ Goal 7: Ensure environmental sustainability } \\
\hline CO2 emissions (kg per PPP \$ of GDP) & $\ldots$ & $\ldots$ & 0 & 0 & 0 \\
\hline CO2 emissions (metric tons per capita) & $\ldots$ & $\ldots$ & 0 & 0 & 0 \\
\hline Forest area (percent of land area) & 65.0 & .. & 57.4 & 53.7 & 49.9 \\
\hline Improved sanitation facilities (percent of population with access) & $\ldots$ & $\ldots$ & 32 & 44 & 50 \\
\hline Improved water source (percent of population with access) & $\ldots$ & $\ldots$ & 52 & 63 & 69 \\
\hline Marine protected areas (percent of territorial waters) & 0 & 0 & 1 & 1 & 7 \\
\hline Net ODA received per capita (current US\$) & 0 & 0 & 279 & 183 & 197 \\
\hline \multicolumn{6}{|l|}{ Goal 8: Develop a global partnership for development } \\
\hline Fertility rate, total (births per woman) & 5 & 6 & 7 & 6 & 6 \\
\hline \multicolumn{6}{|l|}{ Other } \\
\hline GNI per capita, Atlas method (current US\$) & $\ldots$ & $\ldots$ & 330 & 730 & 2,020 \\
\hline GNI, Atlas method (current US\$) (billions) & $\ldots$ & $\ldots$ & 0.3 & 0.7 & 2.2 \\
\hline Gross capital formation (percent of GDP) & $\ldots$ & $\ldots$ & 25.6 & $\ldots$ & $\ldots$ \\
\hline Life expectancy at birth, total (years) & 46 & 51 & 56 & 60 & 62 \\
\hline Literacy rate, adult total (percent of people ages 15 and above) & $\ldots$ & $\ldots$ & 38 & 51 & 51 \\
\hline Population, total (millions) & $\ldots$ & $\ldots$ & 0.8 & 0.9 & 1.0 \\
\hline
\end{tabular}

Source: World Development Indicators database, 2010. 


\section{Appendix I. Timor-Leste's Petroleum Fund and Estimated Sustainable Income}

The Petroleum Fund (PF) is the centerpiece of

Timor-Leste's resource management

framework. It is essentially a government account with the Central Bank to which the country's petroleum receipts are credited and from which debits can be made to finance the state budget. The PF was established with the PF Law in 2005.

- The PF Law defines the estimated sustainable income (ESI) as 3 percent of Timor-Leste's total petroleum wealth that is the current PF balance plus the net present value of future petroleum receipts. The ESI for 2012 is estimated at $\$ 665$ million.

- The ESI is a benchmark to guide budget withdrawals from the PF rather than a rigid fiscal ceiling and to inform policy discussions. Actual withdrawals can exceed the ESI, but the government is required to provide parliament with a justification of why this is in the long-term interest of the country.

- The ESI is calculated every year based on a set of assumptions on petroleum output and prices. The PF law requires the ESI to be estimated using prudent assumptions reflecting international best practice and based upon recognized international standards. The oil prices used are derived from the US Energy Information Administration (EIA) forecast for low sulfur light crude oil, consistent with West Texas Intermediate (WTI), a key benchmark international oil price. The price forecast used is the average of the EIA low and reference case from the 2011 Annual Energy Outlook, which is $\$ 74$ per barrel for 2012. This price is well below the WEO price assumption of $\$ 100$.

- Only projects with approved development plans and firm investment commitments (i.e., the Bayu-Undan and Kitan fields) have been included in the ESI calculation. The Greater Sunrise field has been declared a commercial discovery, but does not yet have an approved development plan. Therefore, Sunrise is not included in the ESI although it is a confirmed petroleum resource.

- The discount rate used for the ESI calculation is the historical 10-year rolling average of U.S. government bond yields for each maturity date, which is 3.7 percent. 


\section{INTERNATIONAL MONETARY FUND}

\section{DEMOCRATIC REPUBLIC \\ OF TIMOR-LESTE}

STAFF REPORT FOR THE 2011 ARTICLE IV

January 13, 2012 CONSULTATION_INFORMATIONAL ANNEX

$\begin{array}{ll}\text { Prepared By } & \text { The Asian and Pacific Department } \\ \text { (In consultation with other departments) }\end{array}$

\section{CONTENTS}

I. FUND RELATIONS . 2

II. WORLD BANK-IMF COLLABORATION ........................................................................ 5

III. RELATIONS WITH THE ASIAN DEVELOPMENT BANK ......................................... 7

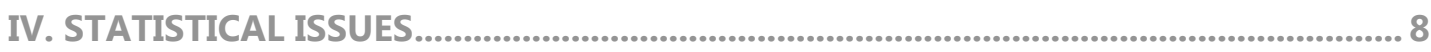




\section{ANNEX I. TIMOR-LESTE: FUND RELATIONS}

(As of December 31, 2011)

\section{Membership Status}

Joined: July 23, 2002; Article VIII

\begin{tabular}{l|c|c|}
\hline \multicolumn{3}{|l}{ II. General Resources Account } \\
\hline & SDR Million & Percent Quota \\
\hline Quota & 8.20 & 100.00 \\
\hline $\begin{array}{l}\text { Fund holdings of } \\
\text { currency }\end{array}$ & 8.20 & 100.00 \\
\hline $\begin{array}{l}\text { Reserve position in } \\
\text { Fund }\end{array}$ & 0.00 & 0.01 \\
\hline
\end{tabular}

III. SDR Department

\begin{tabular}{|l|c|c|}
\hline & SDR Million & Percent Allocation \\
\hline Net cumulative & & \\
\hline allocation & 7.73 & 100.00 \\
\hline Holdings & 7.73 & 100.00 \\
\hline
\end{tabular}

\section{Outstanding Purchases and Loans} None

\section{Latest Financial Arrangements None}

\section{Projected Obligations to Fund None}

\section{Exchange Rate Arrangements}

On January 24, 2000, the U.S. dollar was adopted as the official currency of then East Timor by the United Nations Transitional Administration in East Timor (UNTAET). This arrangement has been maintained after TimorLeste's independence on May 20, 2002. At present, the monetary authority does not undertake foreign exchange transactions; they are handled by commercial banks on the basis of rates quoted in the international markets. Timor-Leste has accepted the obligations under Article VIII, Sections 2(a), 3 and 4, and maintains an exchange system that is free of restrictions on the making of payments and transfers for current international transactions.

\section{Article IV Consultations}

The 2010 Article IV consultation discussions with the authorities were held during October 26-November 9, 2010; the consultation was concluded on January 28, 2011. The Public Information Notice may be found at http://www.imf.org/external/np/sec/pn/2011/p n1131.htm

\section{Technical Assistance}

Since late 1999, a significant amount of technical assistance has been provided by the Fund as part of the international community's efforts to reconstruct the Timor-Leste economy. The Fund's technical assistance has focused on establishing key economic institutions (especially fiscal and monetary authorities) essential for macroeconomic management, as well as on developing local capacity to manage them. It also played a key role in the adoption of a new currency arrangement based on the U.S. dollar. Since late 1999, Timor-Leste has been one of the largest recipients of Fund technical assistance.

FAD: A series of multi-topic FAD missions took place early on to establish and develop the Central Fiscal Authority (CFA, February 2000), which developed into the Ministry of Planning and Finance. Assistance was provided to develop budget preparation, establish tax policy and administration, strengthen treasury and expenditure management, and advise on 
oil sector fiscal regimes. Long-term resident advisors were assigned to the Ministry of Planning and Finance and the Revenue Service of Timor-Leste to cover a wide range of issues, partly under a cost sharing arrangement with the UN. Over August 2004-July 2005, an FAD resident advisor assisted in the design and establishment of the Petroleum Fund, which started operations in August 2005. An FAD resident advisor to the Treasurer of the ministry finance started work in December 2006 to help strengthen expenditure management, reporting and budget execution-after a short break, a replacement has continued this work since July 2008. In 2007, an FAD TA mission provided guidance for future reform of the non-oil tax regime. In April 2009 an FAD technical assistance mission provided advice on implementation of the fiscal regimes for petroleum. In addition to PEFA and fiscal ROSC, in 2010, FAD sent a follow-up mission on treasury management. Also in 2010 and 2011, FAD TA missions provided advice on the calculation of estimated sustainable income from petroleum and other selected petroleum fiscal issues. In 2011, an FAD TA mission provided advice on non-oil tax policy and administration.

LEG: A number of LEG missions have been to Timor-Leste to advise the authorities on key fiscal and financial legislation. These included tax legislation, the budget and financial management law, and banking regulations (relating to the monetary authority, the banking system, and the payments system). Jointly with MFD (now MCM), technical assistance has been provided to assist in drafting an Anti-Money Laundering and Combating the Financing of Terrorism (AML/CFT) Law. LEG also provided assistance, in collaboration with $F A D$, for the drafting of the Petroleum Fund Act and tax consolidation, and in collaboration with MCM, for the drafting of the Central Bank Law.

MCM: A large number of missions took place early on to establish and develop the Central Payments Office (CPO, January 2000), which was transformed subsequently into the Banking and Payments Authority (BPA) (November 2001). Assistance was provided to establish a payments system, prepare banking legislation, and develop key functions of the monetary authority, including banking supervision, asset management, accounting, and organization and management. Assistance was also provided on the introduction of a dollar-based currency system and to issue domestic coins to supplement the use of U.S. dollar coins. More recently, assistance has been provided to (i) draft the insurance law and develop a framework for insurance supervision; (ii) strengthen banking supervision; (iii) address a broad range of issues related to AML/CFT; (iv) establish and train the investment unit responsible for managing petroleum fund assets (funded by Norway, a resident adviser commenced in March 2005 and, after a break due to contract renegotiations, a replacement continued this work from November 2008); (v) prepare for the establishment of the central bank; (vi) design a more effective organizational structure at the BPA; and (vii) modernize payment systems and accounting for the Petroleum Fund. In addition, up until 2006 long-term resident advisors, including on banking supervision, payments, and accounting, were assigned to the BPA under a cost-sharing arrangement with the UN. A long-term resident advisor assisted the BPA General Manager from February 2005 until February 2008, with that support subsequently provided on a peripatetic basis and funded by a Japanese grant. 
STA: A multi-sector statistical mission took place in November 2000 to assess the availability and quality of official macroeconomic data, and help establish the Statistic Division of the Ministry of Planning and Finance. Assistance was provided by long term statistical advisors during November 2001-October 2005. Since 2007, a peripatetic statistical advisor has provided assistance for improving data compilation and developing local capacity to prepare balance of payments statistics-responsibility for this was transferred to the BPA in 2007. Provisional annual balance of payments statements for 2006 and 2007 were published in December 2008. In early 2008 a monetary and financial statistics (MFS) mission helped introduce the standardized report forms (SRFs) for reporting monetary data to the IMF and an integrated monetary database. Subsequently, Timor-Leste published a country page in IFS for the first time. A March 2009 follow-up MFS mission assisted in expanding the institutional coverage of depository corporations to include microfinance institutions and in revising the call report form that will be used to collect balance sheet data. In 2010, STA sent a followup mission on balance of payments statistics and a mission providing assistance on updating the CPI basket. In 2011, STA missions provided advice on external sector statistics and national accounts statistics.

\section{Resident Representative}

The resident representative office in Dili closed at end-June 2009, which was established in August 2000. 


\section{ANNEX II. TIMOR-LESTE: WORLD BANK-IMF COLLABORATION}

1. The Bank and Fund country teams for Timor-Leste, led by Mr. L. Constantino (World Bank country manager) and Mr. B. Jang (Fund mission chief), have closely cooperated on macroeconomic issues and macro-critical structural reforms. The Bank team joined the 2011 Article IV consultation mission.

2. The two teams have worked closely on the following:

- Macroeconomic developments and economic updates: There has been close dialogue throughout the year on macro policies and economic developments. There is regular sharing of information, including Fund comments on the Bank's semi-annual economic updates.

- Public finance management: Bank staff have been following up on the PEFA and ROSC recommendations, including helping the Ministry of Finance (MOF) put together a Strategic Plan. There is regular coordination between Bank staff on the ground and the IMF's Treasury Adviser at the MOF.

- External debt: The teams have engaged very closely on discussions around government plans to borrow. A joint DSA has been conducted in November/December 2011, which is an important building block for the Bank's creditworthiness assessment.

3. The teams agreed that Timor-Leste's main macroeconomic challenge is to manage the country's petroleum wealth effectively and sustainably to develop a stronger non-oil economy and reduce poverty. To meet this challenge Timor-Leste needs to prioritize public expenditure; to strengthen public financial management; and to accelerate reforms to promote productivity and competitiveness. The effectiveness of scaling up public investment will depend critically on progress in these areas. The government launched the Strategic Development Plan (SDP) 2011-30 in July 2011 to step up development.

4. Based on this shared assessment the following structural reform areas were identified as macro-critical:

- Medium-term development plan (MTDP): The SDP envisages a rapid scaling up of public investment. The MTDP should help prioritize public expenditure and promote sustainable growth and fiscal sustainability.

- Public financial management reform: The recent fiscal ROSC and PEFA missions and the Bank's review of the Planning and Financial Management Capacity Building Program found solid progress but also highlighted pressing issues around medium-term budgeting, expenditure (in particular public investment) management and procurement, and auditing. These areas are critical for the quality of expenditure.

- Promoting productivity and competitiveness: Timor-Leste faces a number of challenges to promoting productivity, competitiveness and diversification in the non-oil economy. Three key priorities include addressing skills deficit; improving access to land; and strengthening the business environment, in particular access to finance and contract enforcement.

5. The teams agreed to continue the close cooperation going forward. Table below details the specific activities planned by the two country teams over the December 2011/2012 period. In summary, the Fund will continue to lead on macro issues, and the Bank will continue to lead PFM and macro critical structural reform issues. 
Timor-Leste: Bank and Fund Planned Activities in Macro-Critical Areas

November 2011-December 2012

\begin{tabular}{|c|c|c|c|c|}
\hline & Title & Products & Provisional Timing & $\begin{array}{c}\text { Expected Delivery of } \\
\text { Output }\end{array}$ \\
\hline 1. & $\begin{array}{l}\text { Bank Work } \\
\text { Program }\end{array}$ & $\begin{array}{l}\text { Ministry of Finance } \\
\text { Strategic Plan } \\
\text { Ministry of Finance } \\
\text { PFM Program } \\
\text { Ministry of Finance } \\
\text { design for external } \\
\text { support post-2012 } \\
\text { Parliamentary seminars } \\
\text { on lending, social } \\
\text { transfers } \\
\text { Support on Public } \\
\text { Investment Mgmt } \\
\text { Civil Service wage and } \\
\text { salary bill }\end{array}$ & $\begin{array}{l}\text { Ongoing } \\
\text { March/April } 2012 \\
\text { November } 2011 \text {, } \\
\text { February } 2012\end{array}$ & $\begin{array}{l}\text { June } 2012 \\
\text { June } 2012 \\
\text { September } 2012\end{array}$ \\
\hline 2. & $\begin{array}{l}\text { Fund Work } \\
\text { Program }\end{array}$ & $\begin{array}{l}\text { Article IV Consultations } \\
\text { TA Tax Mobilization } \\
\text { TA Government } \\
\text { Finance Statistics } \\
\text { TA Monetary and } \\
\text { Financial Statistics } \\
\text { TA GDDS } \\
\text { TA PF investment } \\
\text { management } \\
\text { TA Resident Treasury } \\
\text { Advisor } \\
\text { TA ESI and fiscal } \\
\text { regime for petroleum }\end{array}$ & $\begin{array}{l}\text { Missions in November } \\
2011 \text { and September } 2012 \\
\text { Mission in November } 2011 \\
\text { Mission in March } 2012 \\
\text { Mission in Spring } 2012 \\
\text { Mission in March } 2012 \\
\text { Mission in Spring } 2012 \\
\text { Ongoing } \\
\text { Ongoing }\end{array}$ & $\begin{array}{l}\text { January } 2012 \text { and } \\
\text { November } 2012 \\
\text { December } 2011 \\
\text { May } 2012 \\
\text { Spring } 2012 \\
\text { Spring } 2012 \\
\text { Spring } 2012\end{array}$ \\
\hline 3. & $\begin{array}{l}\text { Joint Work } \\
\text { Program }\end{array}$ & DSA update & $\begin{array}{l}\text { Joint mission in November } \\
2011\end{array}$ & January 2012 \\
\hline
\end{tabular}




\section{ANNEX III. TIMOR-LESTE: RELATIONS WITH THE ASIAN DEVELOPMENT BANK}

(As of December 2011)

1. Timor-Leste joined the Asian

Development Bank (AsDB) on July 24, 2002.

The AsDB has been actively involved in the reconstruction and development of the economy since late 1999. To date, there has been no lending to the country.

2. AsDB assistance to Timor-Leste over 1999-2005 had concentrated on emergency infrastructure works. The ADB country strategy for 2006-2010 continued the focus on infrastructure, while completing a transition to rehabilitation works. Over the 2011-15 period AsDB will help the government begin to upgrade infrastructure.

3. The Timor-Leste country partnership strategy (CPS) 2011-15 aligns AsDB support with Timor-Leste's Strategic Development Plan 2011-2030. It outlines a five-year strategic partnership with the government in support of infrastructure, financial services, and the skills training to meet the needs of a growing economy. It will support the private sector to help Timor-Leste make the transition from a public sector-led economy.

4. AsDB resources for infrastructure over the 2011-2015 period are expected to be concentrated in road and urban water supply and sanitation. Support will be private sectororiented, with AsDB playing an "honest broker" role in facilitating private sector engagement in infrastructure.

5. Timor-Leste first accessed the Asian Development Fund (ADF) in 2005. ADF supported activities include an ongoing road rehabilitation project ( $\$ 46$ million grant), a Dili water supply project ( $\$ 6$ million grant), a district capital water supply project (\$11 million grant), and a technical and vocational education and training project (\$11.5 million grant). Timor-Leste is the recipient of one of AsDB's largest ever technical assistance (TA) grant, the Infrastructure Project Management TA. This $\$ 15$ million six-year package, co-financed with AusAID, helps plan, prepare, and execute the Government's capital development program. Other AsDB activities include support for regional economic integration, the finance sector, small-scale infrastructure, and the strengthening of statistics and macroeconomic management, the civil service, and environmental management.

6. To date AsDB has provided a total of 11 grants (5 from the ADF and 6 from the Trust Fund for East Timor) for total amount of $\$ 137.8$ million, and TA projects for a total of $\$ 32.1$ million. Four ADF grants ( $\$ 75.0$ million) and 8 TA projects ( $\$ 19.0$ million) are active.

7. Timor-Leste became eligible to borrow from the ADF in 2011. The $\$ 27.7$ million in ADF resources available for 2011-12 are a mix of grants and loans: $\$ 18.5$ million as grants, and $\$ 9.2$ million as concessional loans. From 201314 , all ADF resources will be available on a loan basis. In October 2011, the ADB Board approved the reclassification of Timor-Leste as a ' $B$ ' member country. This provides access to ADB's Ordinary Capital Resources (OCR), while retaining access to $A D F$. 


\section{ANNEX IV. TIMOR-LESTE: STATISTICAL ISSUES}

(As of December 2011)

\section{Assessment of Data Adequacy for Surveillance}

General: Data provision to the Fund has shortcomings that significantly hamper surveillance. Weaknesses remain in the macroeconomic data, especially the national accounts and trade statistics.

National Accounts: Since April 2009, the authorities have been employing a World Bank funded advisor to develop annual estimates of GDP. The national accounts advisor, with assistance of Fund technical assistance, is finalizing compilation of the national accounts statistics for 2004-10 for the first time. The responsibility of compiling the national accounts data will be handed over to the National Statistical Directorate from the MOF's Macroeconomic Directorate in early 2012. To improve national accounts data further, appropriate staff and substantial efforts in data collection and compilation are needed.

Price statistics: A technical assistance mission during November 8-19, 2010 assisted in rebasing the CPI using data derived from the Timor-Leste Living Standards Survey that was conducted in 2006-7. The CPI basket weights, however, have not been updated yet. Shortcomings in data collection also need to be addressed and products and outlets updated.

Labor market statistics: Annual data on public sector employment and wages are available in official budget documentation. No official data are compiled regularly on private sector employment and wages, except for partial data from various household surveys conducted by UNDP, ILO, ADB, and the World Bank. In 2010, the Macroeconomic Unit in the Ministry of Finance has started to conduct wage surveys.

Government finance statistics: The compilation of revenue and expenditure follows the classification of the Manual on Government Finance Statistics (GFSM 1986) (including expenditure based on both functional and economic classification). These data are bridged to the GFSM 2001 classifications for the compilation of Table 2 of the Staff Report. Only partial data are available on fiscal and quasi-fiscal activities undertaken by bilateral donors outside the central government budget. A technical assistance mission is tentatively scheduled for early 2012 .

Monetary statistics: Monetary statistics are compiled by the Central Bank of Timor-Leste $(\mathrm{CBTL})$, generally following the methodology of the Monetary and Financial Statistics Manual. However, data are incomplete because of the absence of official data on public currency holdings-which are difficult to compile under the current currency regime-and of banks' positions with public nonfinancial corporations.

Detailed monthly monetary data are available from July 2002 onward, following the introduction of the standardized report forms (SRFs). A mission in March 2010 assisted the authorities in finalizing the design of the call report form (CRF) and derived the SRF for the other depository corporations (ODCs) based 
on this revised CRF. A follow-up mission is scheduled for early 2012 to assist the authorities in introducing the SRFs for the central bank based on the new chart of accounts of the CBTL and for the ODCs based on the revised $C R F$ and to include the credit unions in the institutional coverage of the ODCs.

Balance of payments: A major data gap in the monthly data on merchandise exports and imports is the significant underestimation of imports of goods. Also not included are oil and gas exports; an estimate of the large, unrecorded border trade; and some goods exempt from customs duties. Further, customs data may underestimate imports because of undervaluation of declared goods. Monthly merchandise trade data are now published regularly but there are significant gaps in the series for 2006 and 2007. In the Fund staff estimates, data on oil/gas revenue are currently recorded as current income based on fiscal data.

With technical assistance provided by the IMF's Statistics Department, annual balance of payments data are now available for 2006-10.

\section{Data Standards and Quality}

Not a General Data Dissemination System participant.

\section{Reporting to STA}

No data on government finance statistics are currently reported for the GFS Yearbook and the International Financial Statistics (IFS). Beginning in February 2008, monetary data have been reported to the IMF for publication in the IFS.
While methodology for the production of basic annual estimates of the balance of payments statistics are in place, further development work is needed to address limitations of existing data sources, in particular, merchandise trade statistics and travel exports. The coverage of the survey of foreign direct investment enterprises needs to be expanded, and the exploration and extraction activities in the Joint Petroleum Development Area and in the exclusive territory, require ongoing monitoring. As the economy grows, it will be important to monitor new activities such as new direct investment. Currently, there is limited information on remittances from Timorese working abroad and improvement in the estimation/compilation procedures of such remittances should be pursued.

Some data on stocks of financial assets and liabilities have been collected, and the annual international investment position statements should be finalized. Development of quarterly balance of payments statistics should also be pursued.

No Data ROSC is available. 


\section{Timor-Leste: Table of Common Indicators Required for Surveillance}

(As of December 23, 2011)

\begin{tabular}{|c|c|c|c|c|c|}
\hline & $\begin{array}{c}\text { Date of } \\
\text { latest } \\
\text { observation }\end{array}$ & $\begin{array}{l}\text { Date } \\
\text { received }\end{array}$ & $\begin{array}{c}\text { Frequency } \\
\text { of } \\
\text { Data }^{6}\end{array}$ & $\begin{array}{l}\text { Frequency } \\
\text { of } \\
\text { Reporting }^{6}\end{array}$ & $\begin{array}{c}\text { Frequency } \\
\text { of } \\
\text { publication }^{6}\end{array}$ \\
\hline Exchange Rates & $12 / 23 / 2011$ & $12 / 23 / 2011$ & $\mathrm{D}$ & $\mathrm{D}$ & $\mathrm{D}$ \\
\hline $\begin{array}{l}\text { International Reserve Assets and Reserve } \\
\text { Liabilities of the Monetary Authorities }^{1}\end{array}$ & $10 / 2011$ & $11 / 2011$ & M & M & M \\
\hline $\begin{array}{l}\text { Reserve/Base Money (excludes currency in } \\
\text { circulation) }\end{array}$ & $10 / 2011$ & $11 / 2011$ & M & M & M \\
\hline Broad Money (excludes currency in circulation) & $10 / 2011$ & $11 / 2011$ & M & M & M \\
\hline Central Bank Balance Sheet & $10 / 2011$ & $11 / 2011$ & $\mathrm{M}$ & M & M \\
\hline $\begin{array}{l}\text { Consolidated Balance Sheet of the Banking } \\
\text { System }\end{array}$ & $10 / 2011$ & $11 / 2011$ & M & M & M \\
\hline Interest Rates $^{2}$ & $10 / 2011$ & $11 / 2011$ & $\mathrm{M}$ & M & M \\
\hline Consumer Price Index & $10 / 2011$ & $11 / 2011$ & M & M & M \\
\hline $\begin{array}{l}\text { Revenue, Expenditure, Balance and Composition } \\
\text { of Financing }{ }^{3}-\text { General Government }{ }^{4}\end{array}$ & $\ldots$ & $\ldots$ & $\ldots$ & $\ldots$ & $\ldots$ \\
\hline $\begin{array}{l}\text { Revenue, Expenditure, Balance and Composition } \\
\text { of Financing }{ }^{3}-\text { Central Government }\end{array}$ & $12 / 2010$ & $09 / 2011$ & $A$ & $A$ & $A$ \\
\hline $\begin{array}{l}\text { Stocks of Central Government and } \\
\text { Central Government-Guaranteed Debt }\end{array}$ & & & debt contrac & & \\
\hline External Current Account Balance & 2010 & $8 / 2011$ & A & A & A \\
\hline Exports and Imports of Goods and Services ${ }^{5}$ & $8 / 2011$ & $11 / 2011$ & $\mathrm{M}$ & $\mathrm{M}$ & M \\
\hline GDP/GNI & 2010 & $11 / 2011$ & $\ldots$ & $\ldots$ & $\ldots$ \\
\hline Gross External Debt & \multicolumn{5}{|c|}{ Not applicable } \\
\hline International Investment Position ${ }^{7}$ & \multicolumn{5}{|c|}{ Not available } \\
\hline
\end{tabular}

\footnotetext{
${ }^{1}$ Any reserve assets that are pledged or otherwise encumbered should be specified separately. Also, data should comprise short-term liabilities linked to a foreign currency but settled by other means as well as the notional values of financial derivatives to pay and to receive foreign currency, including those linked to a foreign currency but settled by other means. ${ }^{2}$ Both market-based and officially determined, including discount rates, money market rates, rates on treasury bills, notes, and bonds.

${ }^{3}$ Foreign, domestic bank, and domestic nonbank financing.

${ }^{4}$ The general government consists of the central government (budgetary funds, extra budgetary funds, and social security funds) and state and local governments. For Timor-Leste it includes public spending from donors, on which regular data on execution are not available.

${ }^{5}$ Includes only goods. There are significant gaps in the series. No information on services is available.

${ }^{6}$ Daily (D), Weekly (W), Monthly (M), Quarterly (Q), Annually (A); NA: Not Available.

${ }^{7}$ Includes external gross financial asset and liability positions vis-à-vis nonresidents.
} 


\section{INTERNATIONAL MONETARY FUND}

\section{DEMOCRATIC REPUBLIC}

OF TIMOR-LESTE

STAFF REPORT FOR THE 2011 ARTICLE IV

January 13, 2012 CONSULTATION-DEBT SUSTAINABILITY ANALYSIS

\section{Approved By}

Ray Brooks and Dhaneshwar Ghura (IMF)
Prepared $\mathrm{By}^{1}$

International Monetary Fund

International Development Association

Timor-Leste remains at a low risk of debt distress. ${ }^{2}$ This debt sustainability analysis (DSA) updates the joint IMF/IDA DSA from December 3, 2010, to integrate the authorities' new fiscal plans, including new borrowing plans in the proposed 2012 Budget and the Strategic Development Plan. The new fiscal plans aim to frontload capital spending to improve poor infrastructure, which is one of the key constraints to developing the non-oil sector. Under the baseline scenario, all the debt burden indicators remain below their policy-dependent indicative thresholds. However, debt vulnerability may increase as suggested by the higher level of debt service in the longer term associated with the repayment of non-concessional borrowing as evidenced by stress tests. This calls for a cautious approach to such borrowing and emphasizes the importance of prudent debt management.

\footnotetext{
${ }^{1}$ This DSA has been prepared jointly by IMF and World Bank staffs, using the debt sustainability framework for low-income countries approved by the Boards of both institutions.

${ }^{2}$ The DSA presented in this document is based on the standard low-income countries (LIC) DSA framework. See "Debt Sustainability in Low-Income Countries: Proposal for an Operational Framework and Policy implications" (http://www.imf.org/external/np/pdr/sustain/2004/020304.htm) and "Debt Sustainability in LowIncome Countries: Further Considerations on an Operational Framework, Policy Implications" (http://www.imf.org/external/np/pdr/sustain/2004/091004.htm).
} 


\section{UNDERLYING ASSUMPTIONS}

1. This DSA is consistent with the macroeconomic framework outlined in the IMF's staff report for the 2011 Article IV consultation. This DSA continues to use the following adjustments made in last year's DSA in measuring Timor-Leste's repayment capacity: ${ }^{3}$ (i) GNI is used as a proxy for GDP to capture the size of the wider economy; ${ }^{4}$ (ii) wider exports cover exports of nonoil goods and services plus oil-related income recorded in the balance of payments; and (iii) total public sector revenue equals non-oil revenue plus estimated sustainable income (ESI) from petroleum. Compared to last year's DSA, the major differences include the following:

a. More government spending related to scaled up infrastructure expenditure in the medium term. Part of this additional spending is expected to be financed by concessional and non-concessional loans. This DSA includes a total borrowing of US\$486 million for the 2012-16 period envisaged in the proposed 2012 Budget. This amount is about twice the size anticipated at the previous DSA. About $1 / 3$ of these loans is expected to be

\footnotetext{
3 "Democratic Republic of Timor-Leste: Joint World Bank/IMF 2010 Debt Sustainability Analysis" in Democratic Republic of Timor-Leste: 2010 Article IV Consultation-Staff Report, IMF Country Report No. $11 / 65$.

${ }^{4}$ GNI is non-oil GDP plus oil-related income recorded in the balance of payments. Unless otherwise indicated, GDP in the paper (including tables and figures) refers to GNI.
}

concessional, and the others nonconcessional. ${ }^{5}$ After 2016, the amounts of loans are projected to decrease gradually in line with the previous DSA and the Strategic Development Plan for 20112030 (SDP). The total borrowing amount would be 80 percent higher than in the previous DSA. The share of concessional loans is expected to decline gradually, as with rising per capita income, Timor-Leste will no longer be eligible for concessional loans over the long term.

b. A revised macroeconomic framework, including higher nominal non-oil GDP levels and real non-oil GDP growth. The Statistics Office has recently completed compiling the national accounts estimates for 2004-10 for the first time, with assistance from the IMF's Statistics Department. These estimates are much higher than the authorities' earlier estimates (text table) used in the previous DSA. Higher government spending than in the previous DSA mainly reflects the authorities' plan to frontload capital spending to improve poor infrastructure

\footnotetext{
${ }^{5}$ According to the Asian Development Bank, there are two types of loans available for Timor-Leste: the Asia Development Fund (ADF) loans, which are highly concessional, and the Ordinary Capital Resources (OCR) loans, which are non-concessional. The ADF loans are similar to the IDA loans, and the OCR loans are similar to the IBRD loans. Loans with grant elements less than 35 percent are considered nonconcessional.
} 
as envisaged in the 2012 Budget. Over

the long term, the improved

infrastructure is expected to eliminate a

serious binding constraint to growth in

Timor-Leste, leading to higher non-oil

GDP growth. The fiscal and current

account surplus in percent of non-oil GDP

is expected to be much lower than in the previous DSA, reflecting the new nominal

GDP estimates and higher government

spending. Like the previous DSA, the

current DSA only considers oil projects

with an approved development plan and

firm investment commitment (i.e., the

Bayu Undan and Kitan fields) to project

oil-related incomes. ${ }^{6}$

Evolution of selected macroeconomic indicators

\begin{tabular}{|c|c|c|c|c|c|c|c|c|}
\hline & 2008 & 2009 & 2010 & 2011 & 2012 & 2013 & 2014 & 2015 \\
\hline \multicolumn{9}{|c|}{ Nominal non-oil GDP (in millions of U.S. dollars) } \\
\hline Previous DSA & 444.0 & 556.0 & 627.0 & 708.0 & 806.0 & 930.0 & 1068.0 & 1215.0 \\
\hline Current DSA & 634.6 & 789.8 & 875.8 & 1053.9 & 1252.0 & 1487.4 & 1767.0 & 2099.2 \\
\hline \multicolumn{9}{|c|}{ Real non-oil GDP growth } \\
\hline Previous DSA & 11.0 & 12.9 & 6.1 & 7.3 & 8.6 & 9.7 & 9.4 & 8.2 \\
\hline Current DSA & 14.6 & 12.8 & 9.5 & 10.6 & 10.0 & 10.0 & 10.0 & 10.0 \\
\hline \multicolumn{9}{|c|}{ Overall fiscal surplus (in percent of non-oil GDP) } \\
\hline Previous DSA & 431.0 & 239.0 & 239.0 & 210.0 & 179.0 & 115.0 & 122.0 & 107.0 \\
\hline Current DSA & 292.9 & 162.5 & 184.2 & 205.5 & 123.1 & 87.0 & 54.4 & 47.4 \\
\hline \multicolumn{9}{|c|}{ Current account surplus (in percent of non-oil GDP) } \\
\hline Previous DSA & 456.0 & 245.0 & 227.0 & 197.0 & 168.0 & 105.0 & 113.0 & 99.0 \\
\hline Current DSA & 318.8 & 172.6 & 175.6 & 225.3 & 141.6 & 101.2 & 65.5 & 55.6 \\
\hline
\end{tabular}

${ }^{6}$ The Greater Sunrise oil field might be put into production over the DSA projection period. In that case, both the fiscal and current account balances will be improved substantially. 


\section{EXTERNAL DSA}

2. External debt burden indicators under the baseline scenario remain well below their policydependent indicative thresholds throughout the projection period (Figure 1 and Table 1). ${ }^{7}$ Despite the higher government spending on infrastructure and other revisions to the macro framework, the current DSA results are broadly similar to the previous DSA's. However, the standard export shock is no longer the most extreme one in the current DSA owing to changes to exports data. The most extreme shock is generated by the shock to non-debt creating flows, in which all three debt stock ratios temporarily exceed their thresholds (Figure 1).

3. The standard DSA stress tests, however, do not take into account Timor-Leste's special situation as a young post-conflict country and new petroleum producer. These tests are based on historical volatility of the last 10 years, which is particularly high due to internal conflicts between 1999 and 2006 and therefore may not be representative. Moreover, there were sharp increases in GDP due to oil production starting in 2004, resulting in data problems. Specifically the standard shock to non-debt creating flows implies that official transfers, which mainly include donor

\footnotetext{
${ }^{7}$ The indicative external debt burden thresholds for Timor-Leste are shown in Figure 1. They are based on Timor-Leste's classification as a "weak" performer given its (three-year average) score of 2.90 on the World Bank's Country Policy and Institutional Assessment index (CPIA). The CPIA measures the quality of policies and institutions; weak performers score below 3.25, strong performers above 3.75 .
}

assistance and are one of the major sources of current account inflow of Timor-Leste, will show net outflow at 21/2 percent of GDP both in 2012 and 2013 compared with the projected inflow of about 9 percent and $4 \frac{1}{2}$ percent in these two years, respectively. This is highly unlikely given the commitments of donors. ${ }^{8}$ A more realistic severe shock will be a customized non-debt flows shock in which official transfers will be cut to zero. ${ }^{9}$

4. Under the customized non-debt flows shock, Timor-Leste remains at a low risk of debt distress. All debt burden indicators remain under their indicative thresholds (Figure 1 and Table 2). None of the indicative thresholds is breached either under the customized export shock of 60 percent used in the previous DSA.

\footnotetext{
${ }^{8}$ Donor assistance to Timor-Leste is mainly composed of grants from multinational and bilateral donors such as the United Nations, the World Bank, the Asian Development Bank, Australia, and Japan. Historical experience indicates that their commitments are not subject to unexpected, big changes. Moreover, if donor assistance decreases, imports of goods and services for the related projects will decline accordingly. It is also highly unlikely that official transfers will turn negative suddenly, which means Timor-Leste as a poor country begins to provide large grants abroad.

${ }^{9}$ With declines in official transfers, imports are assumed to decline by 70 percent, which are lower than about 80 percent import components of donor assistance in Timor-Leste.
} 


\section{PUBLIC DSA}

5. Indicators of overall public debt (external plus domestic debt) and debt service follow a similar pattern as those for external public debt alone (Table 2 (continued) and Figure 2). With only external borrowing by the government, the results of public debt DSA mirror the external debt DSA. In order to catch the substantial asset accumulation in the Petroleum Fund, TimorLeste's public debt DSA is conducted on a net debt basis (i.e., gross public debt minus the PF assets), which is the same as the previous DSA. Under the baseline scenario and the stress-test scenario of permanently lower GDP growth

\section{CONCLUSION}

6. Timor-Leste remains at a low risk of debt distress. This DSA updates the joint IMF/IDA DSA from December 3, 2010. Compared to the previous DSA, total borrowing for the assessed period increased by 80 percent, as in the proposed 2012 Budget and the Strategic Development Plan. The macroeconomic framework was also updated with new information including the revised national accounts numbers and stepped up government
(Table 3 and Figure 2), all three debt stock and debt-service ratios are projected to rise eventually but net public debt to remain negative (Table 4). However, under the most extreme shock (i.e., primary balance is at historical average minus one standard deviation in 2012-2013), debt-service burden will increase substantially in the long term (Figure 2), and this did not occur in the previous DSA. This reveals the potential vulnerability of Timor-Leste's oil-dependent revenue structure in light of the higher borrowing planned than in the previous DSA.

spending. Under the baseline scenario, all the external debt burden indicators remain below their policy-dependent indicative thresholds. However, debt vulnerability may increase as suggested by the high level of debt service in the longer term associated with the repayment of non-concessional borrowing as evidenced by stress tests. This calls for a cautious approach to such borrowing and emphasizes the importance of prudent debt management. 
Figure 1. Timor-Leste: Indicators of Public and Publicly Guaranteed External Debt under Alternatives Scenarios, 2011-2031 1/
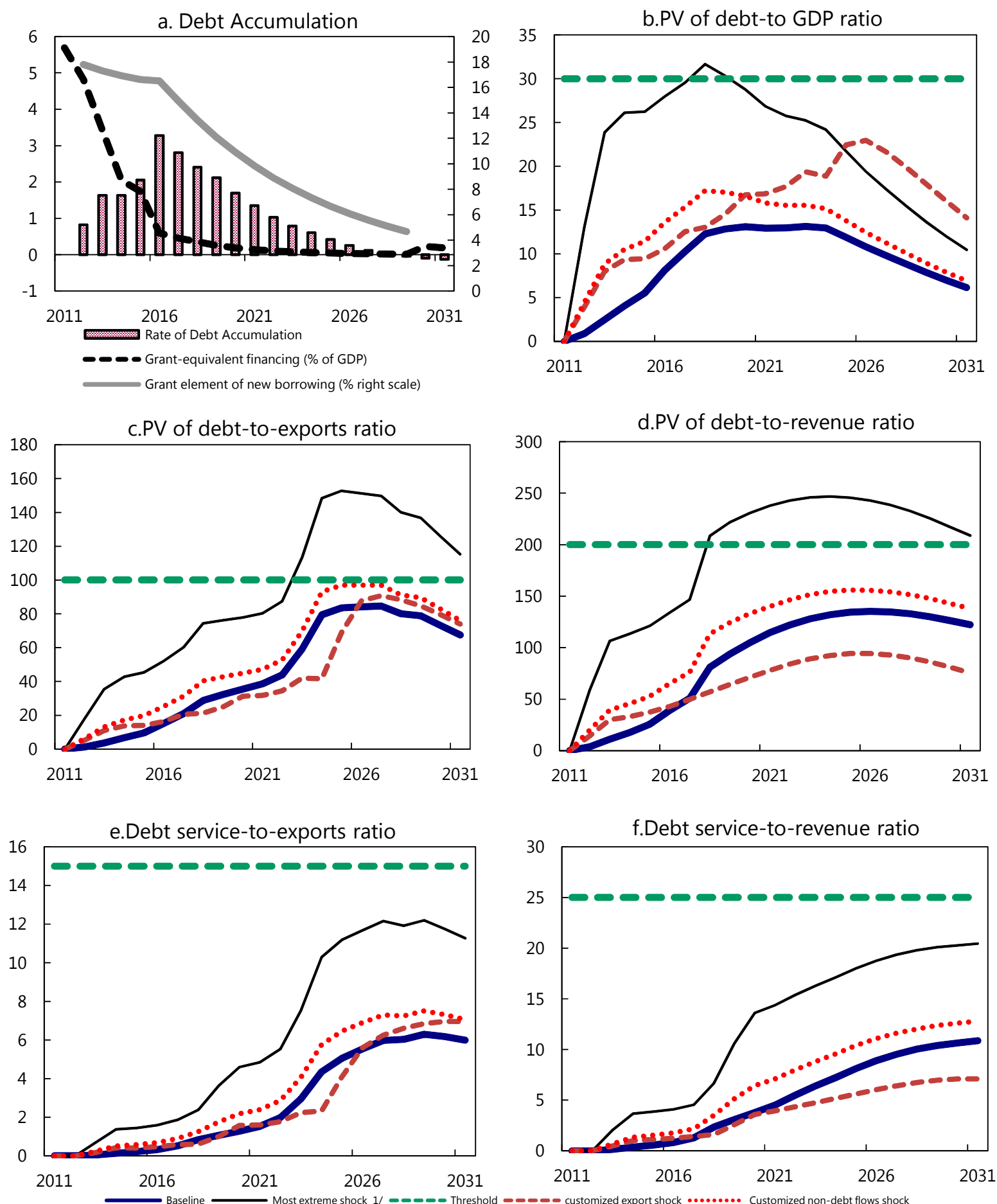

Sources: Timor-Leste authorities; and IMF staff estimates and projections.

1 / The most extreme stress test is the test that yields the highest ratio in 2021 . Figures $b$-f correspond to a nondebt flows shock. 
Figure 2. Timor-Leste: Indicators of Public Debt Under Alternative Scenarios, 2011-2031 1/
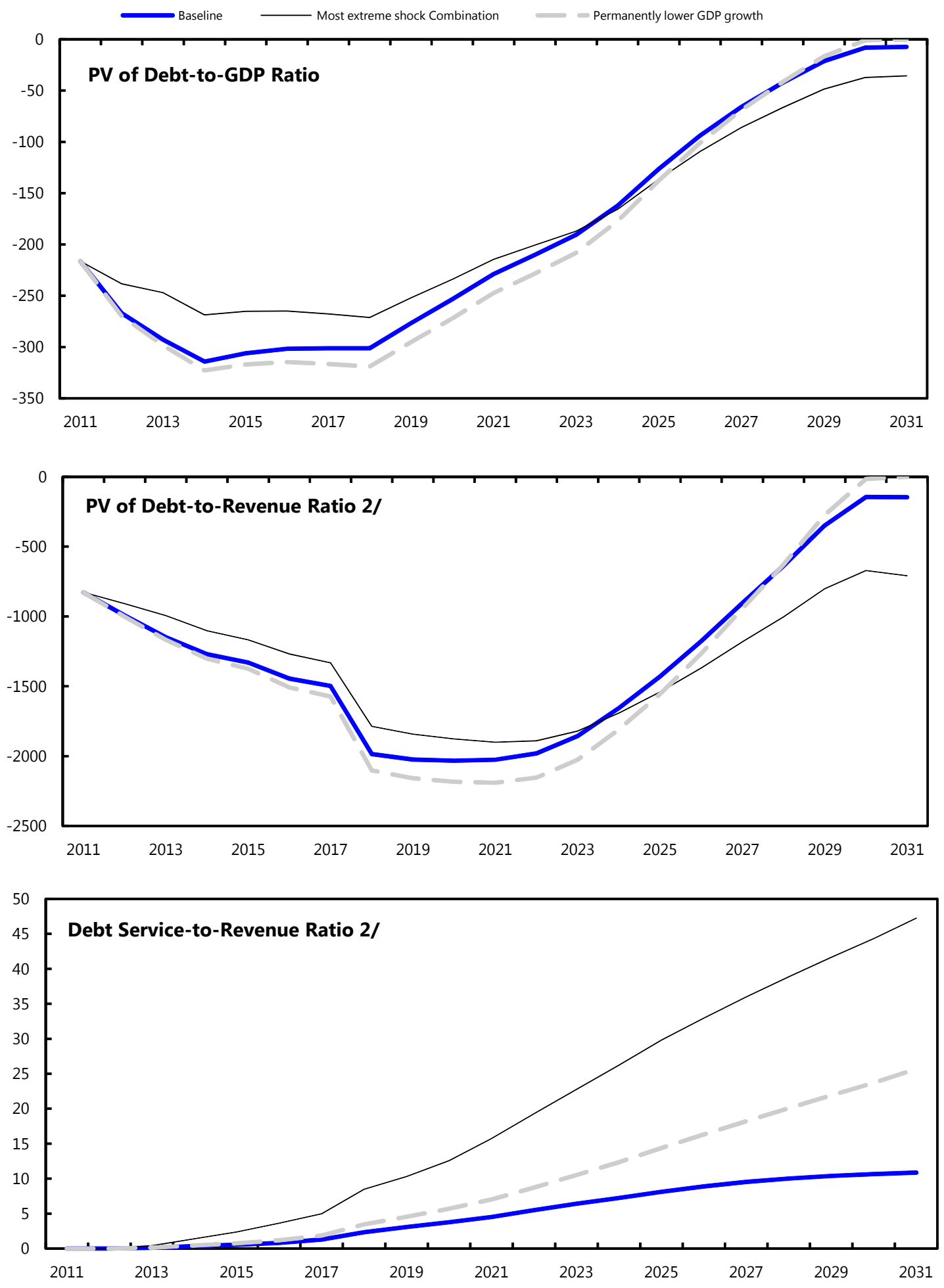

Sources: Timor-Leste authorities; and IMF staff estimates and projections.

$1 /$ The most extreme stress test is the test that yields the highest ratio in 2021.

2/ Revenues are defined inclusive of grants. 
Table 1.Timor-Leste: External Debt Sustainability Framework, Baseline Scenario, 2008-2031 1/

(In percent of GDP, unless otherwise indicated)

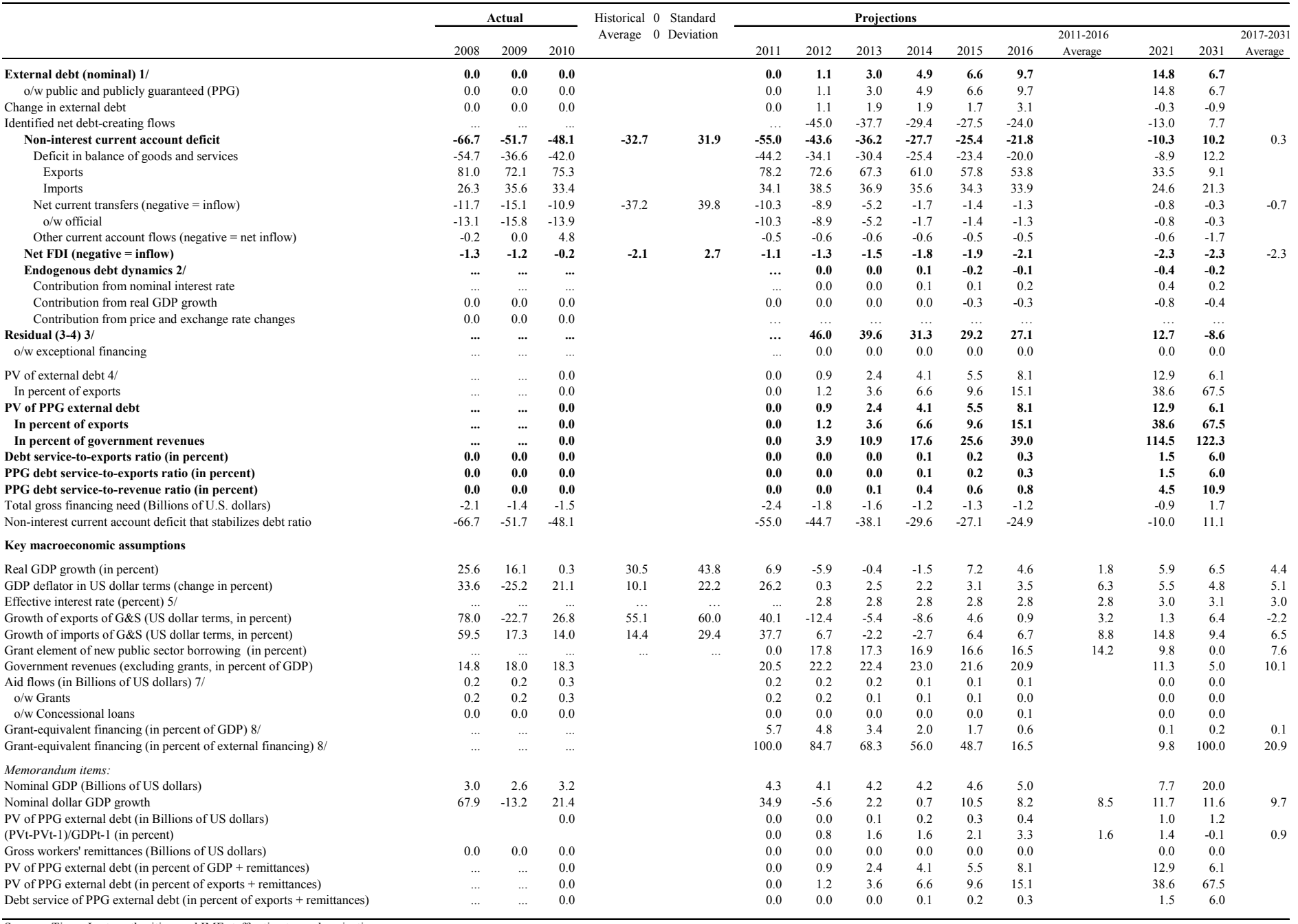

Debt service of PPG external debt (in percent of exports + remittances)

Sources: Timor-Leste authorities; and IMF staff estimates and projections.

2/ Derived as $[\mathrm{r}-\mathrm{g}-\rho(1+\mathrm{g})] /(1+\mathrm{g}+\rho+g)$ times previous period debt ratio, with $\mathrm{r}=$ nominal interest rate; $\mathrm{g}=$ real GDP growth rate, and $\rho=$ growth rate of GDP deflator in U.S. dollar terms.

3/ Includes changes in the PF balances; and valuation adjustments.

4/ Assumes that PV of private sector debt is equivalent to its face value.

$6 /$ Historical averages and standard deviations are generally derived over the past 10 years, subject to data availability.

8/ Grant-equivalent financing includes grants provided directly to the government and through new borrowing (difference between the face value and the PV of new debt). 
Table 2.Timor-Leste: Sensitivity Analysis for Key Indicators of Public and Publicly Guaranteed External Debt, 2011-2031

(In percent)

\begin{tabular}{|c|c|c|c|c|c|c|c|c|}
\hline & \multicolumn{8}{|c|}{ Projections } \\
\hline & 2011 & 2012 & 2013 & 2014 & 2015 & 2016 & 2021 & 2031 \\
\hline \multicolumn{9}{|c|}{ PV of debt-to GDP ratio } \\
\hline Baseline & 0 & 1 & 2 & 4 & 6 & 8 & 13 & 6 \\
\hline \multicolumn{9}{|l|}{ A. Alternative Scenarios } \\
\hline A1. Key variables at their historical averages in 2011-2031 1/ & 0 & 10 & 12 & 5 & -1 & -8 & -46 & -138 \\
\hline A2. New public sector loans on less favorable terms in 2011-2031 2 & 0 & 0 & 2 & 4 & 6 & 9 & 15 & 7 \\
\hline \multicolumn{9}{|l|}{ B. Bound Tests } \\
\hline B1. Real GDP growth at historical average minus one standard deviation in 2012-2013 & 0 & 1 & 3 & 5 & 7 & 10 & 16 & 8 \\
\hline B2. Export value growth at historical average minus one standard deviation in 2012-2013 3/ & 0 & -5 & -9 & -8 & -6 & -3 & 3 & 1 \\
\hline B3. US dollar GDP deflator at historical average minus one standard deviation in 2012-2013 & 0 & 1 & 3 & 5 & 7 & 11 & 17 & 8 \\
\hline B4. Net non-debt creating flows at historical average minus one standard deviation in 2012-2013 4/ & 0 & 13 & 24 & 26 & 26 & 28 & 27 & 10 \\
\hline B5. Combination of B1-B4 using one-half standard deviation shocks & 0 & -32 & -87 & -88 & -81 & -76 & -48 & -13 \\
\hline B6. Customized export shock & 0 & 4 & 8 & 9 & 9 & 11 & 17 & 14 \\
\hline B7. Customized non-debt flows shock & 0 & 4 & 9 & 11 & 11 & 14 & 16 & 7 \\
\hline \multicolumn{9}{|c|}{ PV of debt-to-exports ratio } \\
\hline Baseline & 0 & 1 & 4 & 7 & 10 & 15 & 39 & 67 \\
\hline \multicolumn{9}{|l|}{ A. Alternative Scenarios } \\
\hline A1. Key variables at their historical averages in 2011-2031 1/ & 0 & 14 & 17 & 8 & -2 & -15 & -138 & -1515 \\
\hline A2. New public sector loans on less favorable terms in 2011-2031 2 & 0 & 0 & 3 & 7 & 10 & 17 & 44 & 82 \\
\hline \multicolumn{9}{|l|}{ B. Bound Tests } \\
\hline B1. Real GDP growth at historical average minus one standard deviation in 2012-2013 & 0 & 1 & 4 & 7 & 10 & 15 & 39 & 67 \\
\hline B2. Export value growth at historical average minus one standard deviation in 2012-2013 3/ & 0 & -6 & -12 & -12 & -9 & -5 & 7 & 10 \\
\hline B3. US dollar GDP deflator at historical average minus one standard deviation in 2012-2013 & 0 & 1 & 4 & 7 & 10 & 15 & 39 & 67 \\
\hline B4. Net non-debt creating flows at historical average minus one standard deviation in 2012-2013 4/ & 0 & 18 & 35 & 43 & 45 & 52 & 80 & 115 \\
\hline B5. Combination of B1-B4 using one-half standard deviation shocks & 0 & -36 & -82 & -92 & -90 & -89 & -90 & -92 \\
\hline B6. Customized export shock & 0 & 5 & 11 & 14 & 14 & 16 & 32 & 74 \\
\hline B7. Customized non-debt flows shock & 0 & 6 & 13 & 17 & 20 & 25 & 47 & 76 \\
\hline \multicolumn{9}{|c|}{ PV of debt-to-revenue ratio } \\
\hline Baseline & 0 & 4 & 11 & 18 & 26 & 39 & 114 & 122 \\
\hline \multicolumn{9}{|l|}{ A. Alternative Scenarios } \\
\hline A1. Key variables at their historical averages in 2011-2031 1/ & 0 & 46 & 52 & 22 & -6 & -38 & -408 & -2746 \\
\hline A2. New public sector loans on less favorable terms in 2011-2031 2 & 0 & 1 & 9 & 17 & 27 & 43 & 131 & 149 \\
\hline \multicolumn{9}{|l|}{ B. Bound Tests } \\
\hline B1. Real GDP growth at historical average minus one standard deviation in 2012-2013 & 0 & 4 & 14 & 22 & 32 & 49 & 143 & 152 \\
\hline B2. Export value growth at historical average minus one standard deviation in 2012-2013 3/ & 0 & -22 & -40 & -34 & -27 & -14 & 23 & 20 \\
\hline B3. US dollar GDP deflator at historical average minus one standard deviation in 2012-2013 & 0 & 4 & 15 & 23 & 34 & 52 & 152 & 163 \\
\hline B4. Net non-debt creating flows at historical average minus one standard deviation in 2012-2013 4/ & 0 & 59 & 107 & 113 & 121 & 134 & 238 & 209 \\
\hline B5. Combination of B1-B4 using one-half standard deviation shocks & 0 & -146 & -388 & -383 & -376 & -362 & -422 & -263 \\
\hline B6. Customized export shock & 0 & 14 & 30 & 33 & 37 & 43 & 78 & 76 \\
\hline B7. Customized nondebt flows shock & 0 & 20 & 39 & 46 & 53 & 65 & 140 & 138 \\
\hline
\end{tabular}




\begin{tabular}{|c|c|c|c|c|c|c|c|c|}
\hline & \multicolumn{8}{|c|}{ Projections } \\
\hline & 2011 & 2012 & 2013 & 2014 & 2015 & 2016 & 2021 & 2031 \\
\hline \multicolumn{9}{|c|}{ Debt service-to-exports ratio } \\
\hline Baseline & 0 & 0 & 0 & 0 & 0 & 0 & 2 & 6 \\
\hline \multicolumn{9}{|l|}{ A. Alternative Scenarios } \\
\hline A1. Key variables at their historical averages in 2011-2031 1/ & 0 & 0 & 0 & 0 & 0 & 0 & -3 & -41 \\
\hline A2. New public sector loans on less favorable terms in 2011-2031 2 & 0 & 0 & 0 & 0 & 0 & 0 & 2 & 8 \\
\hline \multicolumn{9}{|l|}{ B. Bound Tests } \\
\hline B1. Real GDP growth at historical average minus one standard deviation in 2012-2013 & 0 & 0 & 0 & 0 & 0 & 0 & 2 & 6 \\
\hline B2. Export value growth at historical average minus one standard deviation in 2012-2013 3/ & 0 & 0 & 0 & 0 & 0 & 0 & $\mathbf{0}$ & 1 \\
\hline B3. US dollar GDP deflator at historical average minus one standard deviation in 2012-2013 & 0 & 0 & 0 & 0 & 0 & 0 & 2 & 6 \\
\hline B4. Net non-debt creating flows at historical average minus one standard deviation in 2012-2013 4/ & 0 & 0 & 1 & 1 & 1 & 2 & 5 & 11 \\
\hline B5. Combination of B1-B4 using one-half standard deviation shocks & 0 & 0 & -1 & -3 & -3 & -3 & -8 & -11 \\
\hline B6. Customized export shock & 0 & 0 & 0 & 0 & 0 & 0 & 2 & 7 \\
\hline B7. Customized non-debt flows shock & 0 & 0 & 0 & 1 & 1 & 1 & 2 & 7 \\
\hline
\end{tabular}

\section{Baseline}

\section{Debt service-to-revenue ratio}

\section{A. Alternative Scenarios}

A1. Key variables at their historical averages in 2011-2031 1/

A2. New public sector loans on less favorable terms in 2011-20312

\section{B. Bound Tests}

B1. Real GDP growth at historical average minus one standard deviation in 2012-2013

B2. Export value growth at historical average minus one standard deviation in 2012-2013 3/

B3. US dollar GDP deflator at historical average minus one standard deviation in 2012-2013

B4. Net non-debt creating flows at historical average minus one standard deviation in 2012-2013 4/

B5. Combination of B1-B4 using one-half standard deviation shocks

B6. Customized export shock

B7. Customized nondebt flows shock

Memorandum item:

Grant element assumed on residual financing (i.e., financing required above baseline) $5 /$

Sources: Timor-Leste authorities; and IMF staff estimates and projections.

1/ Variables include real GDP growth, growth of GDP deflator (in U.S. dollar terms), non-interest current account in percent of GDP, and non-debt creating flows.

2/ Assumes that the interest rate on new borrowing is by 2 percentage points higher than in the baseline., while grace and maturity periods are the same as in the baseline.

3/ Exports values are assumed to remain permanently at the lower level, but the current account as a share of GDP is assumed to return to its baseline level after the shock (implicitly assuming an offsetting adjustment in import levels).

4/ Includes official and private transfers and FDI.

5/ Applies to all stress scenarios except for A2 (less favorable financing) in which the terms on all new financing are as specified in footnote 2 . 
Table 3.Timor-Leste: Public Sector Debt Sustainability Framework, Baseline Scenario, 2008-2031

(In percent of GDP, unless otherwise indicated)

\begin{tabular}{|c|c|c|c|c|c|c|c|c|c|c|c|c|c|c|c|}
\hline & \multicolumn{3}{|c|}{ Actual } & \multirow[b]{2}{*}{ Average } & \multirow[b]{2}{*}{$\begin{array}{l}\text { Standard } \\
\text { Deviation }\end{array}$} & \multicolumn{5}{|l|}{ Estimate } & \multicolumn{5}{|c|}{ Projections } \\
\hline & 2008 & 2009 & 2010 & & & 2011 & 2012 & 2013 & 2014 & 2015 & 2016 & $\begin{array}{l}\text { 2011-16 } \\
\text { Average }\end{array}$ & 2021 & 2031 & $\begin{array}{l}2017-31 \\
\text { Average }\end{array}$ \\
\hline $\begin{array}{l}\text { Public sector debt } 1 / \\
\text { o/w foreign-currency denominated }\end{array}$ & $\begin{array}{r}-138.3 \\
0.0\end{array}$ & $\begin{array}{r}-204.1 \\
0.0\end{array}$ & $\begin{array}{r}-215.8 \\
0.0\end{array}$ & & & $\begin{array}{r}-216.4 \\
0.0\end{array}$ & $\begin{array}{r}-266.8 \\
1.1\end{array}$ & $\begin{array}{r}-292.3 \\
3.0\end{array}$ & $\begin{array}{r}-313.3 \\
4.9\end{array}$ & $\begin{array}{r}-305.0 \\
6.6\end{array}$ & $\begin{array}{r}-300.1 \\
9.7\end{array}$ & & $\begin{array}{r}-227.0 \\
14.8\end{array}$ & $\begin{array}{r}-6.7 \\
6.7\end{array}$ & \\
\hline Change in public sector debt & -22.9 & -65.8 & -11.7 & & & -0.6 & -50.5 & -25.4 & -21.0 & 8.2 & 4.9 & & 24.5 & 0.6 & \\
\hline Identified debt-creating flows & $\ldots$ & $\ldots$ & & & & & -49.4 & -51.8 & -77.1 & -61.9 & -80.2 & & -100.6 & -92.4 & \\
\hline Primary deficit & -0.3 & -2.4 & 6.5 & 1.0 & 4.1 & 7.5 & 12.5 & 14.5 & 16.2 & 16.1 & 16.1 & 13.8 & 15.6 & 11.3 & 15.7 \\
\hline Revenue and grants & 20.9 & 26.2 & 26.6 & & & 26.2 & 26.9 & 25.5 & 24.7 & 23.0 & 20.9 & & 11.3 & 5.0 & \\
\hline of which: grants & 6.1 & 8.2 & 8.2 & & & 5.7 & 4.6 & 3.1 & 1.7 & 1.4 & 0.0 & & 0.0 & 0.0 & \\
\hline Primary (noninterest) expenditure & 20.6 & 23.8 & 33.1 & & & 33.6 & 39.4 & 40.0 & 40.9 & 39.1 & 36.9 & & 26.9 & 16.3 & \\
\hline Automatic debt dynamics & $\ldots$ & $\ldots$ & $\ldots$ & & & $\ldots$ & -12.9 & 5.7 & 2.1 & 30.0 & 23.5 & & 27.2 & 1.4 & \\
\hline Contribution from interest rate/growth differential & $\ldots$ & $\ldots$ & $\ldots$ & & & $\ldots$ & -12.9 & 5.7 & 2.2 & 30.1 & 23.6 & & 27.7 & 1.6 & \\
\hline of which: contribution from average real interest rate & $\ldots$ & $\ldots$ & & & & & 0.7 & 6.7 & 6.6 & 9.0 & 10.2 & & 13.7 & 1.2 & \\
\hline of which: contribution from real GDP growth & 23.6 & 19.2 & 0.6 & & & 13.9 & -13.6 & -1.0 & -4.4 & 21.1 & 13.4 & & 14.0 & 0.4 & \\
\hline Contribution from real exchange rate depreciation & $\ldots$ & $\ldots$ & $\ldots$ & & & ... & 0.0 & 0.0 & 0.0 & -0.1 & -0.1 & & $\ldots$ & $\ldots$ & \\
\hline Other identified debt-creating flows & 0.0 & 0.0 & 0.0 & & & -23.2 & -49.1 & -72.1 & -95.5 & -108.0 & -119.8 & & -143.4 & -105.1 & \\
\hline Privatization receipts (negative) & 0.0 & 0.0 & 0.0 & & & -23.2 & -49.1 & -72.1 & -95.5 & -108.0 & -119.8 & & -143.4 & -105.1 & \\
\hline Recognition of implicit or contingent liabilities & 0.0 & 0.0 & 0.0 & & & 0.0 & 0.0 & 0.0 & 0.0 & 0.0 & 0.0 & & 0.0 & 0.0 & \\
\hline Debt relief(HIPC and other) & 0.0 & 0.0 & 0.0 & & & 0.0 & 0.0 & 0.0 & 0.0 & 0.0 & 0.0 & & 0.0 & 0.0 & \\
\hline Other (specify, e.g. bank recapitalization) & 0.0 & 0.0 & 0.0 & & & 0.0 & 0.0 & 0.0 & 0.0 & 0.0 & 0.0 & & 0.0 & 0.0 & \\
\hline Residual, including the PF asset changes & $\ldots$ & $\ldots$ & $\ldots$ & & & & -1.0 & 26.4 & 56.1 & 70.1 & 85.1 & & 125.1 & 93.0 & \\
\hline \multicolumn{16}{|l|}{ Other S ustainability Indicators } \\
\hline PV of public sector debt & -138.3 & -204.1 & -215.8 & & & -216.4 & -267.0 & -292.8 & -314.1 & -306.1 & -301.7 & & -228.9 & -7.3 & \\
\hline $\mathrm{o} / \mathrm{w}$ foreign-currency denominated & 0.0 & 0.0 & 0.0 & & & 0.0 & 0.9 & 2.4 & 4.1 & 5.5 & 8.1 & & 12.9 & 6.1 & \\
\hline $\mathrm{o} / \mathrm{w}$ external & & & & & & 0.0 & 0.9 & 2.4 & 4.1 & 5.5 & 8.1 & & 12.9 & 6.1 & \\
\hline PV of contingent liabilities (not included in public sector debt) & $\ldots$ & $\ldots$ & $\ldots$ & & & $\ldots$ & $\ldots$ & $\ldots$ & $\ldots$ & $\ldots$ & $\ldots$ & & $\ldots$ & $\ldots$ & \\
\hline Gross financing need $2 /$ & -0.3 & -2.4 & 6.5 & & & 7.5 & 12.5 & 14.6 & 16.3 & 16.2 & 16.2 & & 16.1 & 11.8 & \\
\hline $\mathrm{PV}$ of public sector debt-to-revenue and grants ratio (in percent) & -662.7 & -779.9 & -812.5 & & & -827.1 & -994.3 & -1147.9 & -1269.6 & -1329.9 & -1445.6 & & -2026.5 & -145.8 & \\
\hline PV of public sector debt-to-revenue ratio (in percent) & -935.1 & -1134.8 & -1178.6 & & & -1056.9 & -1201.8 & -1306.4 & -1364.4 & -1414.5 & -1445.6 & & -2026.5 & -145.8 & \\
\hline o/w external 3/ & & & & & & 0.0 & 3.9 & 10.9 & 17.6 & 25.6 & 39.0 & & 114.5 & 122.3 & \\
\hline Debt service-to-revenue and grants ratio (in percent) 4/ & 0.0 & 0.0 & 0.0 & & & 0.0 & 0.0 & 0.1 & 0.3 & 0.5 & 0.8 & & 4.5 & 10.9 & \\
\hline Debt service-to-revenue ratio (in percent) $4 /$ & 0.0 & 0.0 & 0.0 & & & 0.0 & 0.0 & 0.1 & 0.4 & 0.6 & 0.8 & & 4.5 & 10.9 & \\
\hline Primary deficit that stabilizes the debt-to-GDP ratio & 22.6 & 63.4 & 18.2 & & & 8.1 & 63.0 & 40.0 & 37.2 & 7.9 & 11.2 & & -8.9 & 10.7 & \\
\hline \multicolumn{16}{|l|}{ Key macroeconomic and fiscal assumptions } \\
\hline Real GDP growth (in percent) & 25.6 & 16.1 & 0.3 & 30.5 & 43.8 & 6.9 & -5.9 & -0.4 & -1.5 & 7.2 & 4.6 & 1.8 & 5.9 & 6.5 & 4.4 \\
\hline Average nominal interest rate on forex debt (in percent) & $\ldots$ & $\ldots$ & $\ldots$ & $\ldots$ & $\ldots$ & ... & 1.2 & 2.8 & 2.8 & 2.8 & 2.8 & 2.5 & 3.0 & $3.1^{\circ}$ & 3.0 \\
\hline Average real interest rate on domestic debt (in percent) & $\ldots$ & $\ldots$ & $\ldots$ & $\ldots$ & $\ldots$ & $\ldots$ & $\ldots$ & $\ldots$ & $\ldots$ & $\ldots$ & $\ldots$ & $\ldots$ & $\ldots$ & $\ldots$ & $\ldots$ \\
\hline Real exchange rate depreciation (in percent, + indicates depreciation) & -22.7 & 38.0 & -15.3 & -3.1 & 22.1 & -19.5 & $\ldots$ & $\ldots$ & $\ldots$ & $\ldots$ & $\ldots$ & $\ldots$ & $\ldots$ & $\ldots$ & $\ldots$ \\
\hline Inflation rate (GDP deflator, in percent) & 33.6 & -25.2 & 21.1 & 3.6 & 30.4 & 26.2 & 0.3 & 2.5 & 2.2 & 3.1 & 3.5 & 6.3 & 5.5 & 4.8 & 5.1 \\
\hline Growth of real primary spending (deflated by GDP deflator, in percent) & 0.9 & 0.3 & 0.4 & 0.5 & 0.4 & 0.1 & 0.1 & 0.0 & 0.0 & 0.0 & 0.0 & 0.0 & 0.0 & 0.0 & 0.0 \\
\hline Grant element of new external borrowing (in percent) & $\ldots$ & $\ldots$ & $\ldots$ & $\ldots$ & $\ldots$ & $\ldots$ & 17.8 & 17.3 & 16.9 & 16.6 & 16.5 & 17.0 & 9.8 & 0.0 & 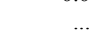 \\
\hline
\end{tabular}

Sources: Country authorities; and staff estimates and projections.

$2 /$ Gross financing need is defined as the primary deficit plus debt service plus the stock of short-term debt at the end of the last period.

$3 /$ Revenues excluding grants.

Debt service is defined as the sum of interest and amortization of medium and long-term debt.

$5 /$ Historical averages and standard deviations are generally derived over the past 10 years, subject to data availability. 
Table 4.Timor-Leste: Sensitivity Analysis for Key Indicators of Public Debt 2011-2031

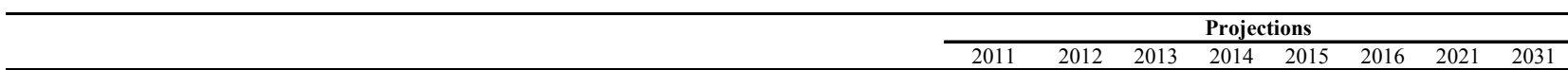

\section{PV of Debt-to-GDP Ratio}

Baseline

\section{A. Alternative scenarios}

A1. Real GDP growth and primary balance are at historical averages

A2. Primary balance is unchanged from 2011

A3. Permanently lower GDP growth $1 /$

\section{B. Bound tests}

B1. Real GDP growth is at historical average minus one standard deviations in 2012-2013 B2. Primary balance is at historical average minus one standard deviations in 2012-2013

B3. 10 percent of GDP increase in other debt-creating flows in 2012

\section{PV of Debt-to-Revenue Ratio 2/}

Baseline

A. Alternative scenarios

A1. Real GDP growth and primary balance are at historical averages

A2. Primary balance is unchanged from 2011

A3. Permanently lower GDP growth $1 /$

\section{B. Bound tests} B2. Primary balance is at historical average minus one standard deviations in 2012-2013

B3. 10 percent of GDP increase in other debt-creating flows in 2012

Debt Service-to-Revenue Ratio 2/

Baseline

\section{A. Alternative scenarios}

A1. Real GDP growth and primary balance are at historical averages

A2. Primary balance is unchanged from 2011

A3. Permanently lower GDP growth 1/

\section{B. Bound tests}

B1. Real GDP growth is at historical average minus one standard deviations in 2012-2013

B2. Primary balance is at historical average minus one standard deviations in 2012-2013

B3. 10 percent of GDP increase in other debt-creating flows in 2012
B1. Real GDP growth is at historical average minus one standard deviations in 2012-2013

$2011 \quad 2012 \quad 2013 \quad 2014 \quad 2015$

$\begin{array}{rrrrrrrr}-216 & -267 & -293 & -314 & -306 & -302 & -229 & -7 \\ & & & & & & & \\ -216 & -200 & -173 & -145 & -120 & -97 & -25 & 2 \\ -216 & -272 & -304 & -334 & -332 & -335 & -279 & -98 \\ -216 & -270 & -298 & -323 & -317 & -315 & -247 & 0\end{array}$

$\begin{array}{llllllll}-216 & -288 & -358 & -379 & -365 & -356 & -257 & 15\end{array}$

$\begin{array}{llllllll}-216 & -274 & -308 & -330 & -321 & -316 & -242 & -16\end{array}$

$\begin{array}{llllllll}-216 & -258 & -284 & -305 & -297 & -294 & -224 & -7\end{array}$

$\begin{array}{llllllll}-827 & -994 & -1148 & -1270 & -1330 & -1446 & -2026 & -146\end{array}$

$\begin{array}{rrrrrrrr}-827 & -782 & -718 & -611 & -542 & -466 & -222 & 41\end{array}$

$\begin{array}{llllllll}-827 & -1011 & -1192 & -1348 & -1444 & -1604 & -2468 & -1962\end{array}$

$\begin{array}{llllllll}-827 & -1002 & -1167 & -1302 & -1373 & -1507 & -2190 & -1\end{array}$

$\begin{array}{rrrrrrrr}-827 & -1057 & -1362 & -1507 & -1564 & -1706 & -2278 & 307\end{array}$

$\begin{array}{llllllll}-827 & -1019 & -1209 & -1334 & -1396 & -1516 & -2141 & -329\end{array}$

$\begin{array}{llllllll}-827 & -960 & -1112 & -1232 & -1292 & -1406 & -1984 & -140\end{array}$

$\begin{array}{llllllll}0 & 0 & 0 & 0 & 1 & 1 & 5 & 11\end{array}$

$\begin{array}{rrrrrrrr}0 & 0 & -1 & -1 & -2 & -2 & -2 & 1 \\ 0 & 0 & -1 & -1 & -2 & -3 & -11 & -75 \\ 0 & 0 & 0 & 0 & 1 & 1 & 7 & 26\end{array}$

Sources: Timor-Leste authorities; and IMF staff estimates and projections.

$1 /$ Assumes that real GDP growth is one percentage point below the baseline.

2/ Revenues are defined inclusive of grants. 


\section{INTERNATIONAL MONETARY FUND}

EXTERNAL

RELATIONS

Public Information Notice

Public Information Notice (PIN) No. 12/8

FOR IMMEDIATE RELEASE

February 1, 2012
International Monetary Fund $70019^{\text {th }}$ Street, NW

Washington, D. C. 20431 USA

\section{IMF Executive Board Concludes 2011 Article IV Consultation with the Democratic Republic of Timor-Leste}

On January 31, 2012, the Executive Board of the International Monetary Fund (IMF) concluded the Article IV consultation with the Democratic Republic of Timor-Leste and considered, and endorsed, the staff appraisal without a meeting. ${ }^{1}$

\section{Background}

After emerging from a long struggle for independence and internal conflicts between 1999 and 2006, Timor-Leste has made substantial progress toward restoring stability and rebuilding the country. Rising government spending and a rebound in agriculture supported strong non-oil gross domestic product (GDP) growth since 2007, averaging 12 percent. Despite unseasonal rain that damaged agricultural produce, growth is estimated to have remained strong at about 10 percent in 2011 on the back of high government spending. Inflation in Dili, however, rose to $171 / 2$ percent (year-on-year) in December 2011, due to high food prices, a weak U.S. dollar, and strong demand from rising government spending, and is becoming broad-based.

The government launched its Strategic Development Plan to transform Timor-Leste into an upper-middle-income country by 2030 . To achieve this goal, the government plans to scale up public investment to improve poor infrastructure. Capital expenditure increased rapidly in 2011 so total government spending is estimated to have risen to \$1.2 billion, from \$0.8 billion in 2010 . Owing to rising petroleum revenue, however, the overall fiscal balance is expected to have continued to record a large surplus of 50 percent of GDP in 2011, and the Petroleum Fund to have risen to about $\$ 9$ billion. Most of the Petroleum Fund is invested in US government bonds.

\footnotetext{
${ }^{1}$ Under Article IV of the IMF's Articles of Agreement, the IMF holds bilateral discussions with members, usually every year. A staff team visits the country, collects economic and financial information, and discusses with officials the country's economic developments and policies. On return to headquarters, the staff prepares a report, which forms the basis for discussion by the Executive Board.
} 
Credit to the private sector has recently started rising after being stagnant for a few years. However, it remains low at only 13 percent of non-oil GDP, reflecting the lack of collateral and weak contract enforcement. These weaknesses together with high nonperforming loans have contributed to high lending rates in Timor-Leste. Nonperforming loans are high at almost 40 percent of total loans but are fully covered by provisions. Three foreign bank branches dominate the financial sector. The Banking and Payments Authority was recently transformed to a central bank, with no change in its function. The U.S. dollar is the legal tender.

The current account surplus is estimated to have remained large at over 50 percent of GDP in 2011 due to high oil revenue. Non-oil exports, excluding coffee, are minimal and the country depends highly on imports given almost no domestic production base except subsistence farming and coffee. Foreign assets rose to an all-time high at 170 months of imports. The real effective exchange rate appreciated by 6 percent in 2011.

The outlook for growth and poverty reduction is promising as Timor-Leste stands to benefit enormously from its petroleum wealth in coming years. Using this wealth, the government has resolved to step up development. With rising government spending, non-oil GDP growth is projected to remain strong at about 10 percent in 2012 and over the medium term and the current account surplus is projected to decline. Key risks to the outlook are high inflation, a fall in oil prices, and slow progress in building public financial management capacity.

\section{Executive Board Assessment}

In concluding the 2011 Article IV consultation with Timor-Leste, Executive Directors endorsed staff's appraisal as follows:

Rising government spending has supported strong economic growth, but inflation has jumped to double digits. Using its petroleum wealth, the government has resolved to step up development by scaling up investment in infrastructure. Real non-oil GDP growth is projected to remain strong at about 10 percent in 2012 and over the medium term. Key risks to the outlook are oil price volatility and the possibility that inflation continues to rise on the back of large increases in government spending.

Given development needs, investment in infrastructure is welcome, but the planned increase of spending over the next few years needs to be slowed to better align with the absorptive capacity of the economy and administrative constraints. Continued large increases in government spending would raise inflationary pressure further, and high inflation will impose significant costs on the poor. In the absence of monetary policy, sound fiscal policy is key to containing high inflation and sustaining strong economic growth. The government's intention to consider adjusting the pace of 2012 budget execution if inflation remains high is welcome. Staff stressed the importance of continued progress in improving the capacity to implement capital projects.

The authorities' plan to reduce the non-oil fiscal deficit to a sustainable level over the next 10 years is appropriate. This will provide an important anchor for fiscal policy. To achieve this 
goal, the government may need to take substantial measures, including containing spending growth and increasing domestic revenue. In addition, the medium-term budget framework needs to be strengthened by including the full costs of planned major projects and recurrent costs once they are available. The authorities' intention to review the recent Fiscal Affairs Department mission's recommendations to raise non-oil revenue, including the introduction of a value added tax over the medium term, is welcome. Repealing the very generous tax holidays under a new private investment law is recommended.

The government has made solid progress in improving public financial management (PFM). A well-managed Petroleum Fund is in place. Further progress has been made in addressing the weaknesses in PFM by establishing new institutions to strengthen public investment management. The lack of skilled personnel is the key constraint to PFM so the government's focus on training Timorese should help build capacity.

Developing the financial sector and strengthening the credit culture are critical for sustained growth in the private sector. The Central Bank's continued efforts to strengthen financial sector supervision and regulations are welcome. Banks tightened their lending standards and improved credit assessments. Speeding up the passage of key legislations such as the land law would help financial sector development.

The use of the U.S. dollar is appropriate given the limited capacity for independent monetary and exchange rate policies. Non-oil exports, excluding coffee, are minimal and the country depends highly on imports. Accelerating structural reforms is needed to improve competitiveness. Prudent fiscal policy will be key to maintaining external stability over the long term.

Data quality and availability need to be improved. More staff and training are needed to improve the data necessary for policy analysis and formulation.

Public Information Notices (PINs) form part of the IMF's efforts to promote transparency of the IMF's views and analysis of economic developments and policies. With the consent of the country (or countries) concerned, PINs are issued after Executive Board discussions of Article IV consultations with member countries, of its surveillance of developments at the regional level, of post-program monitoring, and of ex post assessments of member countries with longer-term program engagements. PINs are also issued after Executive Board discussions of general policy matters, unless otherwise decided by the Executive Board in a particular case. The staff report (use the free Adobe Acrobat Reader to view this pdf file) for the 2011 Article IV Consultation with the Democratic Republic of TimorLeste is also available. 
Timor-Leste: Selected Economic and Financial Indicators, 2007-12

GDP at current prices (2010): US $\$ 3.2$ billion

Population (2010): $\quad 1.1$ million

GDP per capita (2010): $\quad$ US $\$ 2,908$

Non-oil GDP per capita (2010): US $\$ 821$

Quota: SDR 8.2 million

\begin{tabular}{|c|c|c|c|c|c|}
\hline 2007 & 200 & 200 & 201 & 2011 & 2012 \\
\hline
\end{tabular}

Real sector

Real non-oil GDP growth

CPI (annual average) 2/

CPI (end-period) 2/

(Annual percent change)

Central government operations

Revenue

Domestic revenue

Petroleum revenue

Expenditure

Recurrent expenditure

Capital expenditure

Overall balance

Non-oil overall balance (in percent of non-oil GDP)

Money and credit

Deposits 3/

Credit to the private sector $3 /$

Lending interest rate (percent) $3 /$

Balance of payments

Current account balance

(In percent of GDP)

Trade balance

Exports 4/

Imports

Petroleum revenue

Overall balance

Public foreign assets (end-period) 3/ 5/

(In months of imports)

Exchange rates

NEER (2000 $=100$, period average) $3 /$

REER (2000 $=100$, period average) $3 /$

NEER (2000 $=100$, end-period) $3 /$

REER ( $2000=100$, end-period) $3 /$

Memorandum items:

GDP at current prices:

Non-oil GDP 6/

Oil GDP 7/

Crude oil prices (U.S. dollars per barrel, WEO) 8/

Petroleum Fund balance (in millions of U.S. dollars) 3/

Petroleum Fund balance (in percent of non-oil GDP) 3/

Public debt (in millions of U.S. dollars)

Sources: Timor-Leste authorities; and IMF staff estimates and projections.

1/ Staff proposals.

2/ For Dili (capital city). The countrywide CPI is available on a quarterly basis only.

3/ Data for 2011 is as of end-October.

4/ Excludes petroleum exports, the income of which is recorded under the income account.

$5 /$ Includes Petroleum Fund balance and the central bank's official reserves.

$6 /$ Based on the resident national accounts advisor's new estimates.

7/ Petroleum revenue is used as a proxy for oil GDP.

8/ September 2011 WEO assumptions. 